$1-1-1965$

\title{
Marketing practices of West Virginia lumber producers
}

D. E. Nelson

Follow this and additional works at: https://researchrepository.wvu.edu/ wv_agricultural_and_forestry_experiment_station_bulletins

\section{Digital Commons Citation}

Nelson, D. E., "Marketing practices of West Virginia lumber producers" (1965). West Virginia Agricultural and Forestry Experiment Station Bulletins. 507.

https://researchrepository.wvu.edu/wv_agricultural_and_forestry_experiment_station_bulletins/471 @ WVU. It has been accepted for inclusion in West Virginia Agricultural and Forestry Experiment Station Bulletins by an authorized administrator of The Research Repository @WVU. For more information, please contact ian.harmon@mail.wvu.edu. 
West Virginia University Libraries

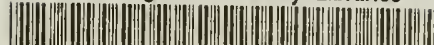


Digitized by the Internet Archive in 2010 with funding from Lyrasis Members and Sloan Foundation 


\section{MARKETING PRACTICES}

\section{OF}

\section{WEST VIRGINIA}

\section{LUMBER PRODUCERS}

Bulletin 507

June 1965 


\section{THE AUTHORS}

D. E. Nelson, Instructor in Wood Technology, Division of Forestry, and a former Research Assistant in the Agricultural Experiment Station, is working on his doctorate in forestry at the University of Michigan; W. W. Christensen and W. H. Reid, both former Associate Foresters in the Experiment Station, are now with the U. S. Forest Service; N. D. Jackson is Assistant Forester in the Experiment Station.

West Virginta Untversity Agricultural Experument Station

College of Agriculture, Forestry and Hoife Economics

A. H. Vanlandlingham, Director

Morgantown 


\section{5-66}

\section{West Virginia University}

\section{Mountaineers}

\section{GYMNASTICS}

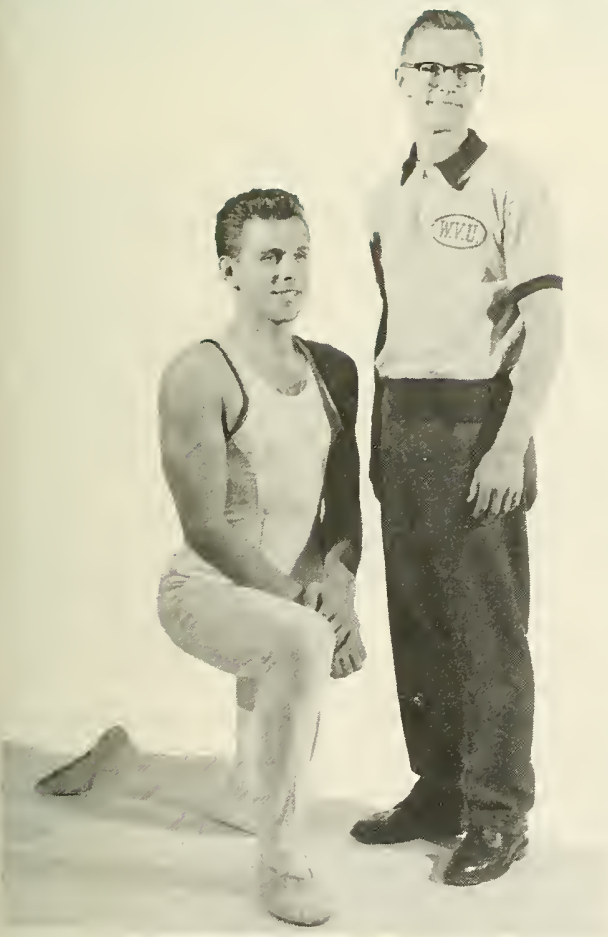

Captain Ken Musko and Coach Bill Bonsall

\section{CHAMPIONS}

NCAA SOUTHERN DISTRICT

1965 


\section{Focts A bout The WVU MOUNTAINEERS}

LOCATION ...........Morgantown, W. Va. 26506 FOUNDED .......... February 7, 1867 (98th year ENROLLMENT .............11,514 (1965-66. NICKNAME ...... Mountaineers (NOT "mounties" COLORS ............... Old Gold and Blue CONFERENCE .......... Southern (July I, 1950 . PRESIDENT ............ Paul Ausborn Miller' 3 ; ATHLETIC DIRECTOR .... Robert N. "Red" Browr GYMNASTICS ............William Bonsali PUBLICITY DIRECTOR ............ Edgar Barret ASST. PUBLICITY DIRECTOR ........ Roger Ruhl (In charge of gymnastics)

\section{OUTLOOK}

The best gymnast in West Virginia history has graduated, but the Mountaineers still figure to keep on winning.

Coach Bill Bonsall, now in his 14 th year as coach, is gunning for his fifth straight winning season. His recent prosperity followed nine years without a winning season. Bonsall's career record is $35-47-1$, but his teams have won 23 while losing only nine over the last four seasons.

To keep winning Bonsall must replace Jerry Spencer, the man he called "one of the ten best gymnasts in the country" last year. Spencer accounted for 316 points a season ago, more than half of the team's total. In one dual meet he captured every first place and scored 84 points.

Four men return from last season's team which finished 6.2 and took the NCAA Southern district championship. Captain Ken Musko in the only senior. Juniors Bob Rajchel and Jack Carter are the top returning scorers. Mike Knaggs, a specialist on the still rings, also returns.

A pair of all-around sophomores move up to the varsity and both have the potential to blossom into outstanding performers. Eddie Cross won three gold and three silver medals in the Western Pennsylvania Regional Invitational and captured the meet's allaround event last year. Bonsall calls him and Ed Ehler "welcome additions" to this year's weakened team. Other newcomers to the team include Jim Bays, Ron Curfman, and Danny Deems. 


\section{ROSTER}

\begin{tabular}{|c|c|c|}
\hline Nome & Event & Hometown \\
\hline Bays & Free Exercise & Allentown, $\mathrm{Pa}$. \\
\hline k Carter & $\begin{array}{l}\text { Parallel Bars } \\
\text { Horizontal Bar }\end{array}$ & Westbury, N. \\
\hline Cross & All Around & Parkersburg \\
\hline n Curfman & All Around & Parkersburg \\
\hline nny Deem & $\begin{array}{l}\text { Parallel Bars } \\
\text { Still Rings }\end{array}$ & Parkersburg \\
\hline Ehler & All Around & Wheeling \\
\hline se Knaggs & Still Rings & Elkins \\
\hline n Musko & All Around & Butler, Pa. \\
\hline b Rajchel & All Around & Butler, $\mathrm{Pa}$. \\
\hline
\end{tabular}

\section{SCHEDULE}

c. 11 Virginia at Charlottesville

n. 8 Western Reserve, Kent State at Cleveland, O.

n. 15 VMl at Morgantown

b. 2 Merchant Marine at New York, N. Y.

b. 3 Coast Guard at New London, Conn.

b. 5 William and Mary at Williamsburg, Va.

b. 19 Eastern Michigan, Slippery Rock at Slippery Rock, Pa.

b. 22 Pitt at Morgantown

tr. 4-5 Southern Intercollegiate Championship at Furmañ University, Greenville, S. C.

1r. 18-19 U.S.G.F. Championships at Slippery Rock, $\mathrm{Pa}$.

r. 1-2 NCAA Championships at Penn State, University Park, Pa.

\section{4-65 RESULTS}

$$
\text { (Won 6, Lost 2) }
$$

30 Penn State, away .........66 66

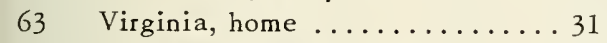

70 Chicago, home.......... 50

$55 \frac{1}{2}$ Georgia Southern, home ..... . 40

$56 \frac{1}{2}$ Slippery Rock, away . . . . . . 4 4 $41 \frac{1}{2}$

76 Ithaca, away ............ 20

35 Pitt, away .............61

$591 / 2$ Georgia Tech, home ........ 37/2

1st - NCAA Southern District Championships 
ALL.TIME SERIES RECORDS

\begin{tabular}{lcccc} 
Team & Began & Won & Lost & Tiei \\
Army & $1957-58$ & 0 & 1 & 0 \\
Ball State & $1960-61$ & 2 & 1 & 0 \\
Chicago & $1960-61$ & 3 & 0 & 0 \\
Citadel & $1963-64$ & 1 & 0 & 0 \\
Cortland & $1961-62$ & 2 & 0 & 0 \\
Duke & $1952-53$ & 0 & 1 & 0 \\
Georgia Tech & $1956-57$ & 3 & 1 & 0 \\
Georgia Southern & $1963-64$ & 1 & 1 & 0 \\
Illinois State & $1962-63$ & 1 & 0 & 0 \\
Illinois (Chicago) & $1954-55$ & 0 & 2 & 0 \\
Ithaca & $1961-62$ & 2 & 0 & 0 \\
Lock Haven & $1955-56$ & 3 & 1 & 0 \\
Massachusetts & $1958-59$ & 0 & 1 & 0 \\
Michigan & $1959-60$ & 0 & 1 & 0 \\
Navy & $1955-56$ & 0 & 5 & 0 \\
North Ca rolina & $1952-53$ & 0 & 2 & 0 \\
Ohio State & $1953-54$ & 0 & 5 & 0 \\
Penn State & $1953-54$ & 0 & 9 & 0 \\
Pitt & $1953-54$ & 4 & 10 & 0 \\
Slippery Rock & $1960-61$ & 4 & 1 & 0 \\
Springfield & $1958-59$ & 0 & 1 & 0 \\
Temple & $1955-56$ & 0 & 3 & 0 \\
Virginia & $1962-63$ & 3 & 0 & 0 \\
W'est Chester & $1954-55$ & 5 & 1 & 1 \\
Western Illinois & $1962-63$ & 1 & 0 & 0 \\
\multicolumn{1}{c}{ Totals } & & 35 & 47 & 1
\end{tabular}

SEASON BY SEASON

$\begin{array}{ccccc}\text { Year } & \text { Won } & \text { Lost } & \text { Tied } & \begin{array}{c}\text { Coach } \\ 1952-53\end{array} \\ 1953-54 & 2 & 2 & 0 & \text { Bill Bonsal } \\ 1954-55 & 3 & 3 & 0 & \text { Bill Bonsal } \\ 1955-56 & 0 & 3 & 0 & \text { Bill Bonsal } \\ 1956-57 & 2 & 4 & 0 & \text { Bill Bonsal } \\ 1957-58 & 2 & 4 & 0 & \text { Bill Bonsal } \\ 1958-59 & 1 & 5 & 0 & \text { Bill Bonsal } \\ 1959-60 & 1 & 6 & 0 & \text { Bill Bonsal Bonsal } \\ 1960-61 & 1 & 4 & 0 & \text { Bill Bonsal } \\ 1961-62 & 4 & 3 & 1 & \text { Bill Bonsal } \\ 1962-63 & 8 & 1 & 0 & \text { Bill Bonsal } \\ 1963-64 & 5 & 3 & 0 & \text { Bill Bonsal } \\ 1964-65 & 6 & 2 & 0 & \text { Bill Bonsal } \\ & & & & \end{array}$




\section{Table of Contents}

Page

SUMMARY

Form

Condition

12

Species Groups

15

Geographical Destination

Type of Outlet

Grade 22

Type of Manufacture

PRICES PAID FOR LUMBER MARKETED 26

Effect of Grading and Marketing Effort Upon Price 27

Bargaining Position

Method, Type and Terms of Sale 31

Reasons for Selling to Buyers 32

IRADE AND VOLUME DETERMINATION 33

NVENTORY ON HAND

JONCLUSIONS

ITERATURE CITED 


\section{Summary}

The market for lumber from sawmills is not a competitive market. In a competitive market prices for a certain product are related to costs, but market imperfections in the lumber market allow buyers (and, infrequently, sellers) to practice price discrimination. This results in a variety of prices for the same product-an imperfect market. The objective of this study is to describe the market for lumber in West Virginia, with particular attention to possible causes for market imperfections.

A random sample of West Virginia lumber producers who market lumber was selected for personal interview. The 133 producers interviewed marketed about one-third of the estimated 405 million board feet of lumber marketed in West Virginia in 1957.

Three size classes were recognized. Small firms marketed less than one-half million feet per year. Medium-size firms marketed over one-half but less than three million board feet. Large firms marketed three million or more board feet. The data on marketing practices indicate that there are substantial differences between firms, and that the small firms are at a particular disadvantage.

Firms which marketed lumber also produced other wood products. Small firms produced greater volumes of other wood products than they did lumber-mostly low-value products such as mine timbers and railroad ties. Large firms produced mostly lumber, some mine timbers, and considerable volumes of such high-value products as flooring and dimension stock.

Not all of the lumber marketed by the firms in this study was produced by them. Some of the larger firms assumed a wholesaler's role by purchasing lumber and then reselling it along with the lumber they produced. Lumber purchases for resale were most common with the large firms, where almost 10 per cent of the lumber sold had been purchased. Smaller firms handled a smaller percentage in this manner.

Total lumber marketed by West Virginia firms in 1957 was an estimated 405 million board feet, of which only 34 million board feet was softwood. Oak and yellow-poplar accounted for two-thirds of the hardwood lumber. Hemlock was by far the most common softwood. The bulk of the lumber marketed was hardwood in air-dried condition and in rough form. A considerable amount of green hardwood lumber was marketed, especially by the smaller firms.

Over 200 million board feet of West Virginia hardwood lumber was marketed out-of-state, primarily in V'irginia, North Carolina, Pennsylvania, and Ohio. A large volume of the more desirable species and better grades is used in the manufacture of furniture by firms outside the State. 
Much of this lumber was supplied by large firms. The principal product manufactured within the State was oak flooring, produced from low-grade lumber supplied by the smaller firms.

The smaller firms marketed a higher proportion of the poorer grades of lumber than did the large firms. Twelve per cent of the hardwoods was sold as ungraded lumber.

The largest initial market outlet for lumber was the manufacturer, followed by the wholesaler, the consumer, and the retailer. Wholesalers dealt mainly with the better grades. It is reasonable to assume that much of the lumber handled through wholesalers was resold to manufacturers. Furniture and flooring accounted for over 70 per cent of the lumber marketed to manufacturers.

Prices paid by buyers to West Virginia lumber producers were generally less than the accepted market price. Large firms, for example, were paid prices near the accepted market price, but small firms received an average of $\$ 60.00$ per thousand board feet less than the large firms did for the better grades of lumber. This trend was present for all grades and all species. Firms selling through wholesalers were not so likely to receive as high a price as those selling through manufacturers, but the average price paid by manufacturers was only slightly higher than the average price paid by wholesalers. Large firms which sold to wholesalers received higher prices than did small firms for the same product.

The firms which spent time locating markets for their lumber received higher prices than those firms which did not. When the price of the lumber was determined by bargaining, it varied according to which party was in the stronger bargaining position. The seller's price approached the accepted market price; the buyer's price was considerably lower; and the compromise price fell in between. Small firms were often forced to sell at the buyer's price because they lacked bargaining power.

Most lumber sellers demanded cash payment within 30 days. Small firms favored the buyer who offered the best price, paid cash on delivery, would buy all grades, and would buy when the market was poor. Large firms favored the buyer who represented reputable firms. Large firms measured and graded the lumber they sold, while many small firms were forced to sell at a price based upon the buyer's determination of grade and lumber volume.

Small firms were often forced to sell green lumber in order to pay current operating expenses. For many, severe capital limitations precluded the holding of the large lumber inventories needed in order to yield additional revenue through the sale of air-dried lumber. Larger 
firms, normally without this capital limitation, maintained sufficient lumber inventories to capitalize on the higher price paid for air-dried lumber. They also used their inventories as an indication of market conditions. When markets were good, inventories decreased, and production was accelerated to compensate. When markets were poor, inventories increased and production was cut back. The firms with abundant capital could wait for a favorable market price, while those without capital were forced to sell regardless of the market conditions.

The market for West Virginia lumber does not approach the "ideal" market in which there is a single price for a standard product. As long as there is such a great difference in size between firms and such a serious lack of capital by producers, there will be different bargaining positions, resulting in price differences. The bargaining position of smaller producers, however, can be improved by stronger marketing effort, cooperative marketing, widespread price reporting, and the help of federal or state marketing specialists, and extension personnel. Marketing publications like this can only indicate the extent of the market imperfections. Other public or private institutions may wish to consider actual solutions. 


\section{Marketing Practices \\ Of West Virginia Lumber Producers}

\section{E. Nelson, W. W. Christensen, W. H. Reid, and N. D. Jackson}

\section{Introduction}

Manufacture of lumber implies sale of lumber, therefore lumber producers must be marketers of their product as well as producers. Although considerable literature is available on the production of lumber, surprisingly little exists on the marketing of this product. This bulletin reports on the marketing practices of West Virginia producers who market lumber. The few producers who do not market lumber either manufacture a product other than lumber, or custom-saw logs not owned by them. These producers are excluded from this report.

During the present century, West Virginia has been one of the nation's leading producers of hardwood lumber. Since 1900, for example, the State has ranked first annually on fifteen occasions." During the period 1900 to 1957, an estimated 28 billion board feet of hardwood lumber was produced in the State-about 8 per cent of the total national production. Almost half of this production was oak lumber.

Some indication of how this huge volume of lumber was utilized is contained in a 1914 report by Nellis and Harris (1914). This study was conducted to "... determine the extent to which lumber is further manufactured within the State of West Virginia." This report listed products of West Virginia’s wood-using industry, stating that for the year 1912 about 250 million feet of the 1,250 million feet produced was re-manufactured into products within West Virginia. That "West Virginia's wood-using industries are not highly developed, and a large part of its lumber is being sent away from home to be further manufactured" is a situation which is true even today.

* The years in which West Virginia ranked first in hardwood lumber production are 1907, 1910, 1911, 1912, 1913,1914,1915, 1916, 1917, 1932, 1939, 1940, 1941, 1942 , and 1946. The peak production year was 1909, when 1,524 mills cut 908 million board feet of hardwood lumber. The 1958 hardwood production figures show West Virginia as ranking tenth in the nation, behind Virginia, Tennessee, Mississippi, North Carolina, Arkansas, Louisiana, Pennsylvania, Alabama, and Missouri, in that order Hardwood lumber production in 1958 was 285 million board feet in West Virginia. (Data from H. B. Steer, Lumber Production in the U.S. 1799-1946. USDA Misc. Publ. No. 669, and U.S. Bureau of Census, Current Industrial Reports Lumber Production and Mill Stocks, 1959 and 1958 Series M24T(59)-1, Washington 25, D. C. 1961.) 
Both lumber production and lumber re-manufacturing in West Virginia have decreased since 1912; at present an estimated 60 million feet of lumber is manufactured into products within the State, compared with 250 million in 1912 (Reid and others, 1961).

When centers of lumber production are remote from centers of manufacturing, producers are often forced to rely upon market intermediaries to perform the marketing function. In this case, the returns to the producer may be lower because of lack of knowledge as to better alternative markets for this lumber. This problem is especially true for West Virginia since a majority of the wood-using industries are located at considerable distances from the State's sawmills.

\section{Research Procedure}

The marketing information on which this bulletin is based was obtained through personal interviews with a large number of West Virginia sawmill owners who were producing lumber for market. These owners were selected at random after stratifying the universe of mill owners both geographically by counties and by mill-size class within selected counties. A total of 133 sawmill owners was sampled of the 604 which composed the universe.

Twenty-two large-mill ownerships accounted for over 40 per cent of the total lumber volume marketed (Table 1). The medium-size mills, totaling 162 units, accounted for another 40 per cent of the lumber market, leaving less than 20 per cent of the market for the remaining 70 per cent of the mills-those with an annual production of less than one-half million board feet.

Because sampling percentage varied within the three size-class strata, a blow-up factor was computed for each of these classes. This factor was based upon the number of mill ownerships in each size class. Most of the data contained in this report is the estimated total derived from the blown-up data, which permits more valid comparisons between the three size-classes of mills. When actual sample data is presented, it will be designated as such.

\section{Composition of the Sawmill Industry}

During the past fifteen years, the number of sawmills in West Virginia has decreased from 1,558 (Steer, 1948) to 824 (West Virginia University, 1959). Most of this reduction has occurred in the inefficient small-mill category. There is, however, evidence of a continued entrance

-Size classes used in this analysis are: Small mills-marketing from 1,000 board feet to 499,000 board feet annually; Medium mills-marketing from 500,000 board feet to $2,999,000$ board feet annually; Large mills-marketing 3,000,000 or more board feet annually. 
of new firms into the industry. For example, although all of the large firms surveyed reported that they had been in business for more than five years, over 10 per cent of the small firms in this survey indicated that they had started production within the last five years. Additionally, nearly 5 per cent of the medium-sized firms had also entered business during this period. However, many of these new entrants represent new management of already existing mills. Viewed from a profit standpoint, the future of these new firms appears questionable, particularly for those in the small-size mill class. Many mills of this size have been buying logs F.O.B. mill for an average price of $\$ 44.00$ per thousand board feet (West Virginia Forest Products Market Information, 1960) and selling lumber, mainly as ungraded, for $\$ 60.00$ per thousand board feet (Table $5)$. Assuming that milling costs average $\$ 12.50$ per thousand board feet (Forest Products Price Bulletin, 1962), a margin of $\$ 3.50$ per thousand board feet has been realized, which is equal to a $\$ 14.00$ per day return for mills cutting 4,000 board feet per day. However, if a reasonable charge were made to cover depreciation of the fixed investment, it is likely that a net loss would result.

Although some small mills have been forced to close, many remain in production. The output of lumber is not concentrated in a few large firms. Lumber production is among the very least concentrated industries in the nation. Primary aluminum production, for example, is entirely controlled by only three companies. Total production of the largest twenty sawmill and planing mill companies accounts for only 18 per cent of total U. S. output (Zaremba, 1963). This means that no single company is large enough to influence the national price for lumber. With respect to industry concentration the lumber industry is a good example of free competition. This seems to indicate that there is a place for the efficient small producer in the industry, provided that economies of scale in lumber production do not rule out the small sawmill.

The wide range in annual production which exists between mills seems to indicate that there is no optimum-size mill for all areas. Some West Coast mills cut over 200 million board feet of lumber annually (Lumberman, April, 1959), which is equal to about one-half of the total cut in West Virginia. The largest mill in West Virginia cuts between 15 and 20 million board feet annually (Lumberman, May, 1959), while the vast majority of mills in West Virginia cut less than one-half million board feet per year. Some of these small mills are able to make a profit even though they may be competing against mills fifty times larger. Apparently the nature of this industry is such that economies of scale from a production standpoint are sometimes offset by dis-economies of supply, so that mills can be competitive over a fairly wide range of sizes. 
The present trend is toward the medium-size, automated mill.

Table 1 presents sampling and lumber marketing data for the sawmills covered in this study.

\section{Types of Products Produced by Sawmills}

Sawmills which produce lumber for the market also produce some other products. In this study, lumber was defined as any wood sawed from logs eight feet and longer in length, yielding boards having two parallel plane faces that measure, in the least dimension, 4 inches or less in softwoods and 6 inches or less in hardwoods. This does not include railroad ties, mine timbers, and industrial blocking. Under this definition, lumber accounted for over 62 per cent of the total volume of products produced by West Virginia mill owners who market lumber. ${ }^{*}$

Table 2 summarizes the types of products produced by the sampled mills. All sawmill products produced at these mills were converted to board foot equivalents to permit a comparison of the relative importance of the various types of products.

Table 2 shows that almost half of the total product output of the small sawmills was in the production of mine materials. Flooring comprised slightly over 7 per cent of total product output, considerably more than that of the medium mills. However, this apparent inconsistency arises because the small sawmill class included the flooring production of one large flooring mill which sold a small amount of lumber in the reporting year and was therefore placed in the class of mills which marketed small amounts of lumber. If the classifications had been based upon lumber volume produced rather than the volume of lumber marketed, this particular flooring mill would have been included in the large mill-size. class, since it produced millions of board feet of lumber, all of which was subsequently converted into flooring.

Mine materials and railroad ties were less important products for large mills than for small mills. Such bulky, low-value products are typically sawn from low-grade logs-a process requiring little in the way of specialized equipment. These low-value products cannot be hauled long distances at a profit and, consequently, are usually processed by the small mills located near this type of product market. By contrast, manufacture of flooring and dimension stock requires more expensive, specialized equipment. Moreover, these higher-value products can be profitably shipped over longer distances.

"Throughout this bulletin the terms "West Virginia mill owners," "lumber producers," and "sawmills which produce lumber for the market," are all used somewhat interchangeably. To be included in this study, a producer was defined as one who sold at least two-thirds of the total lumber handled by his firm annually. 


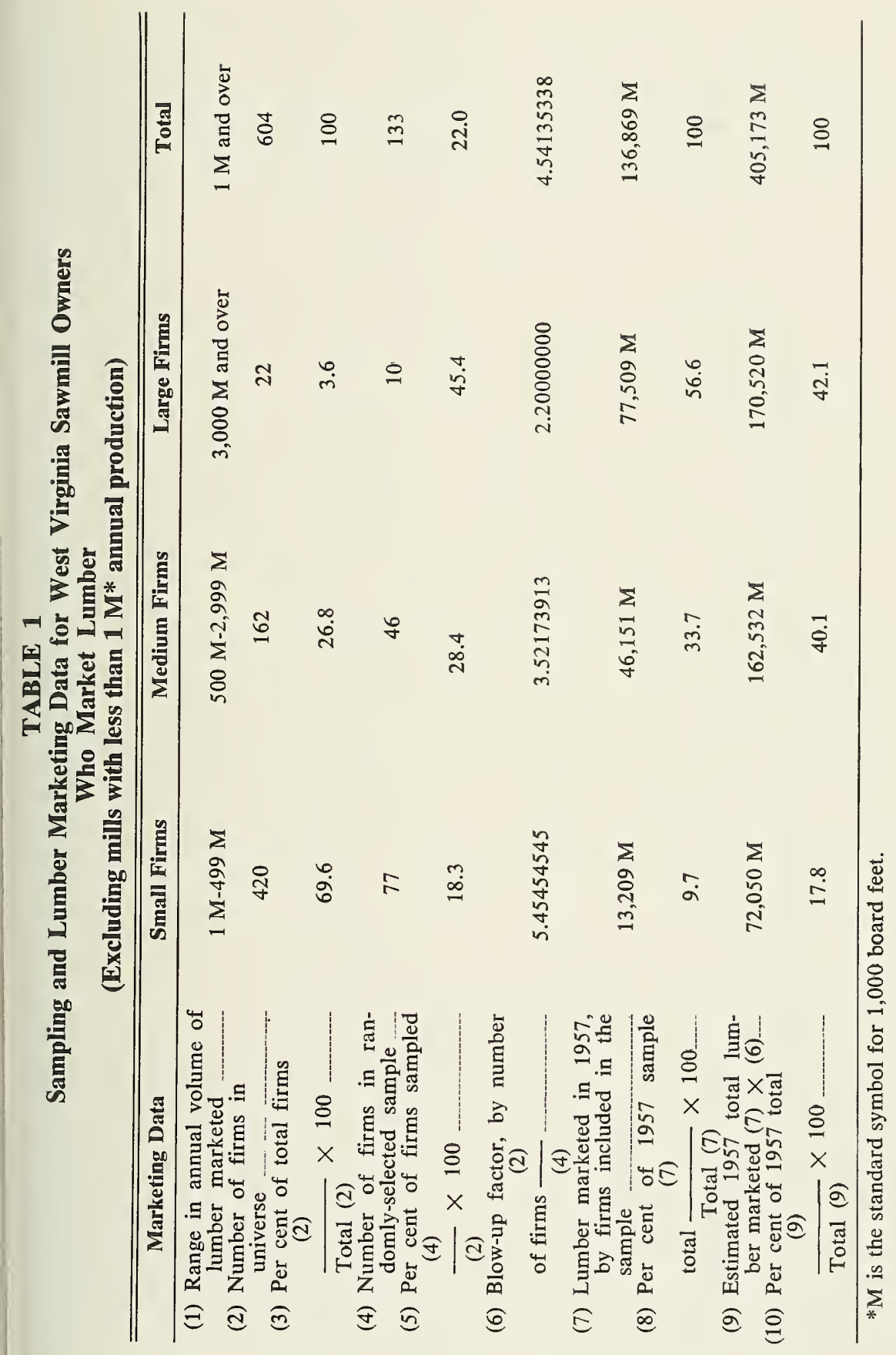




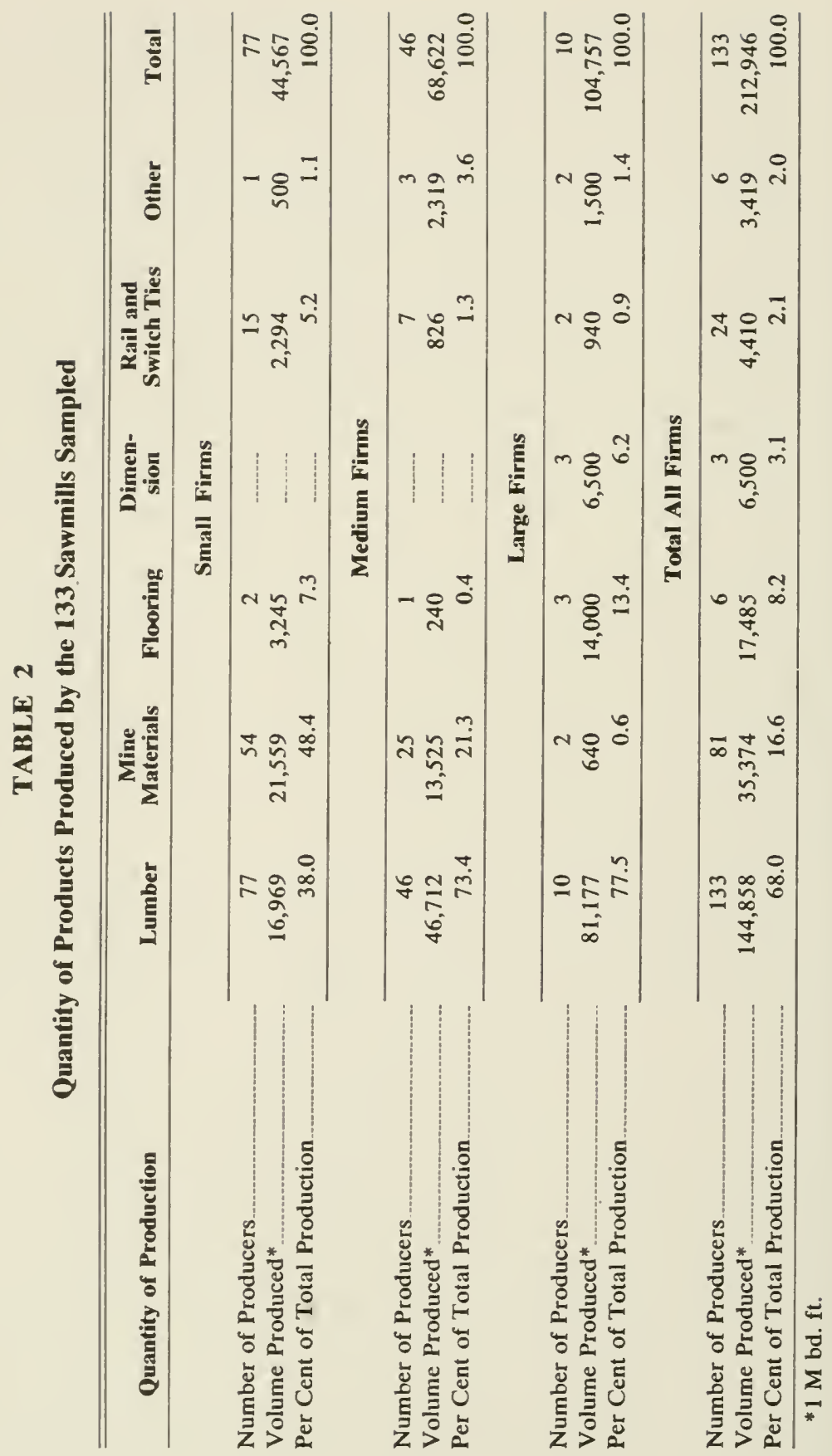




\section{Lumber Production by Ownership Type}

Of the 133 mills in the study, all but ten processed their own logs. Nine mills, eight of which were in the small class, custom sawed logs belonging to other persons, but the total volume which was custom sawed amounted to less than one-half of 1 per cent.

\section{Lumber Marketed}

The volume of lumber marketed by any sawmill owner consists of the volume sold from his own production plus the lumber volume that may have been purchased for resale. This wholesaleing function occurred mainly in the large size-class firms. However, the purchase and resale of lumber comprised only 10 per cent of the total lumber marketed by these large units. Of the total lumber they marketed, small firms purchased 2 per cent and medium firms purchased 4 per cent. More than 93 per cent of the lumber marketed in this study was manufactured by the sawmill firm that sold it.

The characteristics of the raw material, or the resulting products, affect the marketing practices of firms. For example, hardwood lumber typically flows through different marketing channels than softwood lumber, primarily because hardwoods usually are destined for a manufactured product of one form or another, whereas softwoods are channeled predominantly into the construction field. As might be expected in a state that principally supports hardwood timber growth, this study shows that of the 405 million board feet of lumber marketed, only 34 million feet was softwood lumber. Over half of the mills in West Virginia did not market any softwood lumber.

\section{Form of Lumber Markefed}

The term "form," as used here, refers to the surface condition of lumber marketed, i.e., lumber sold as rough lumber or as dressed or planed lumber. As shown in Figure 1, less than one-tenth of the hardwood lumber was sold in dressed form, and by way of contrast, almost one-half of the softwood lumber was so marketed. But for both species groups, more of the dressed lumber was marketed by large firms, principally because it is the large mills which have the necessary machinery for the surfacing operation.

Only small amounts of hardwood lumber are marketed in dressed form, probably' because most of the end uses for hardwood lumber demand machining to precise manufacturer's dimensions. Such specifications are difficult to meet without well-kiln-dried lumber and special surfacing equipment specifically designed for surfacing short, relatively 
clear pieces. For this reason, manufacturers who use hardwood lumber prefer to purchase it in a green or air-dried condition and in rough form. As the initial step in manufacturing, the lumber is dried to the moisture content best suited to a particular product; the rough boards are crosscut into relatively clear pieces; and one true, plane surface is established by passing the piece through a special jointer. ${ }^{\circ}$

Some soft hardwoods, yellow-poplar (Liriodendron tulipifera, L.) and basswood (Tilia americana, L., or T. heterophylla, Vent.), are sometimes surfaced and used much as construction softwoods would be used. Some dense hardwoods are surfaced on a conventional planer when intended for use in low-valued products like pallets or crating, where the surface qualities are not as demanding as in most manufactured products made from hardwood.

\section{Condition}

Condition of lumber refers to its moisture content, i.e., whether or not the lumber is in a green state, has been air seasoned at the mill yard, or has been kiln dried. Condition is shown graphically in Figure 2.

As revealed in Figure 2, hardwoods were mainly sold in an air-dried or green condition, because the users of hardwood often prefer to control the moisture content themselves. Furthermore, even if lumber is dried at the mill to a proper moisture content, there is the possibility that this moisture content may change excessively during handling and shipping operations. Figure 2 also shows that only the larger marketing size classes sold kiln-dried lumber. This is as might be expected because the smaller firms typically do not process and market lumber in sufficient volume to justify a kiln installation. Although well-air-dried lumber commands a better price on the market, the small firms sold a large proportion of their lumber in green condition, probably because they were unable to afford holding the large inventories needed to capitalize on the delayed returns which accompany air drying.

Air-dried or green softwoods are satisfactory for many construction uses. The large West Coast producers of softwood lumber often kiln dry,

- The jointer used to surface hardwood for manufactured products is not the same type used to surface softwood construction lumber. In surfacing softwood lumber for construction, the board is flattened by the pressure exerted by the planer feed rollers as it is surfaced. The resulting surface is smooth but most of the original cup is still present in the board after surfacing. For construction, this is not too objectionable because much of this cup can be removed in the construction by nailing. When pieces of rough hardwood boards are surfaced they are held down on the planer table at many points by spring loaded fingers which exert little pressure, so that the resulting surface is a true, plane surface. It is not possible or desirable to do this for an entire board. If a sawmill were to produce pieces of the type described, it would be in reality producing dimension stock. 


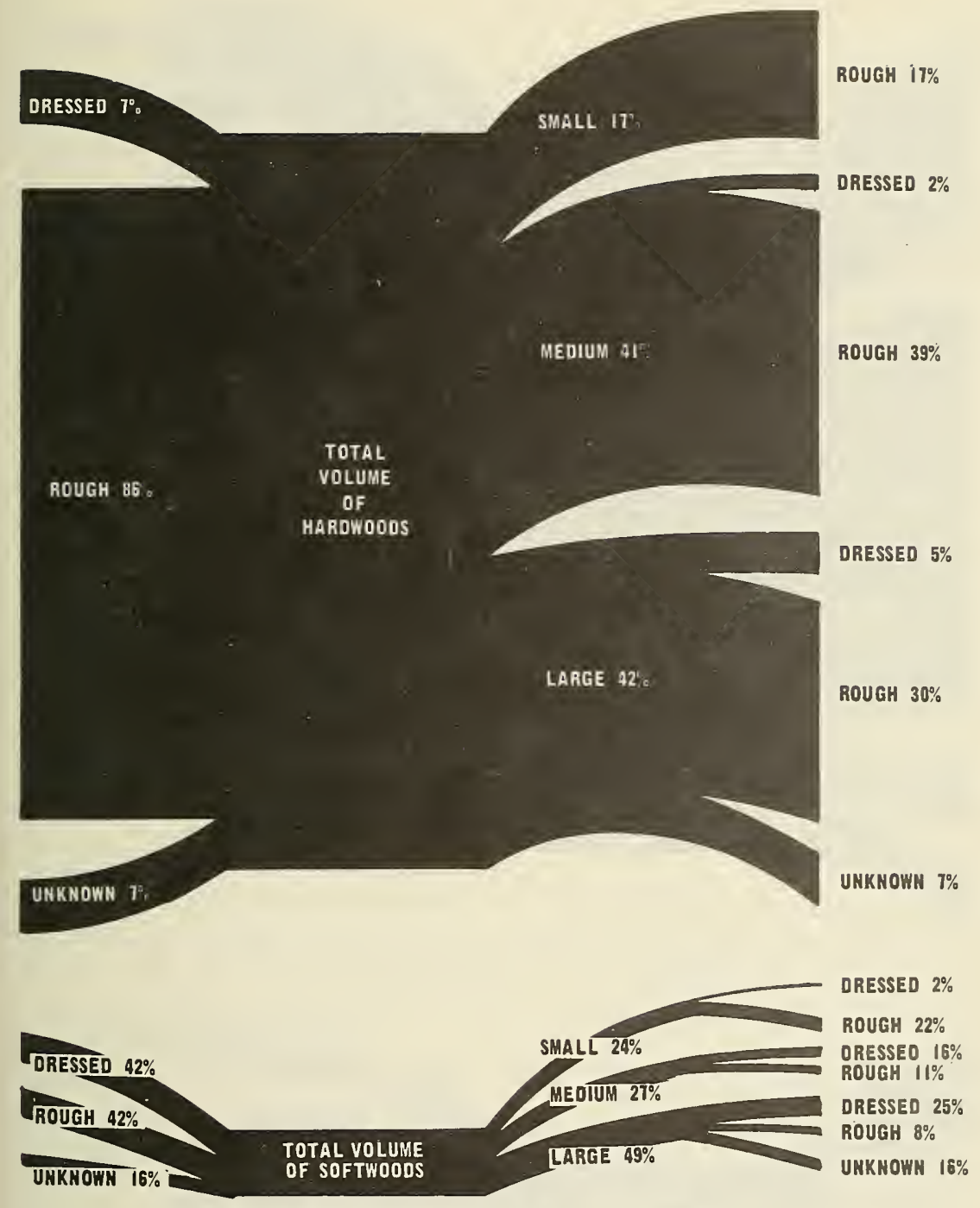

FIGURE 1. Form of lumber marketed by mill size.

but this is sometimes done to reduce shipping weight and inventories, rather than to improve the product. "Where softwoods are to be used

*At this writing, adoption of the American Lumber Standards Committee's proposed revision to the softwood lumber standards is being considered by the U. S. Department of Commerce. This proposed standard specifies that softwood lumber has a "maximum" moisture content of 19 per cent. Well-air-dried lumber, by contrast, can become as dry as 12-14 per cent, in which case it would be better for construction than kiln dried to a maximum of 19 per cent. 

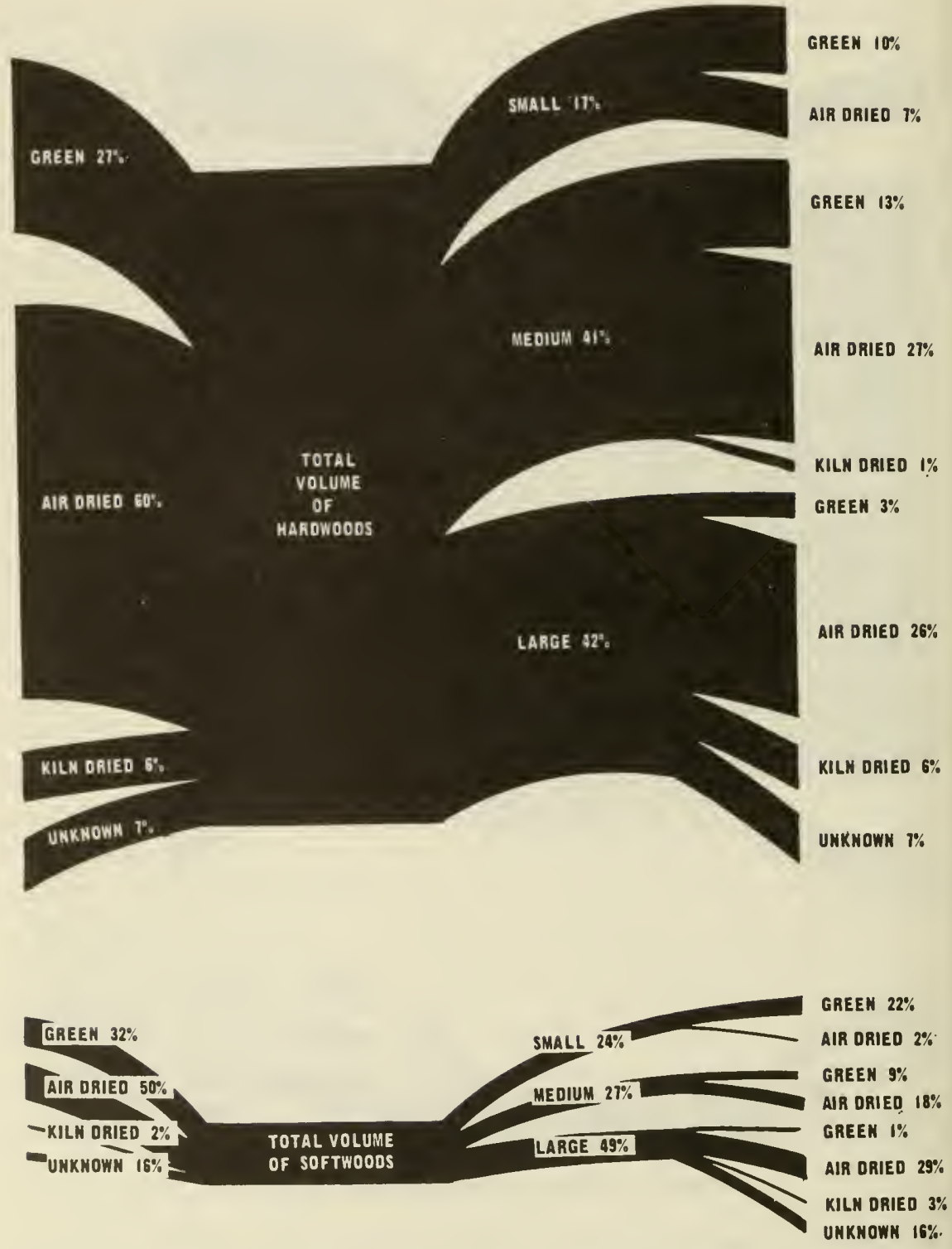

FIGURE 2. Seasoning condition of lumber when sold.

locally for construction, well-air-dried lumber is often drier than kilndried lumber from the West Coast. Green softwoods can be used satisfactorily in pallets and crates and in some types of building construction. 


\section{Species Groups}

Figure 3 shows that almost two-thirds of the hardwood lumber marketed was oak (Quercus spp.) and yellow-poplar. These species groups accounted for about three-fourths of the lumber marketed by the small and medium mills. A fair amount of maple (Acer spp.) and birch (Betula spp.) was marketed-mostly by the larger firms.

Hemlock (Tsuga canadensis [L.] Carr.) was the most common softwood, accounting for over 40 per cent of the total softwood lumber. White pine (Pinus strobus L.) and one of the southern yellow pines (Pinus echinata Mill.) were the only other softwoods marketed in fairly large volume.

Over the past fifty years there have been some changes in the species production of lumber in West Virginia. Oak, for example, was the leading species group in 1907, followed by hemlock. Spruce (Picea rubens, Sarg.) was third, yellow-poplar fourth, and chestnut (Castanea dentata [Marsh] Borkh.) was fifth. Each of these species groups accounted for over 100 million board feet of lumber produced in 1907 (Steer, 1948). In 1957, oak was the only species group which accounted for over 100 million board feet, followed by lesser amounts of yellow-poplar, maplebirch, ${ }^{*}$ hemlock, white pine, cherry (Prunus serotina, Ehrh.) and southern yellow pine, respectively.

\section{Geographical Destination}

Much of the lumber produced in West Virginia is marketed outside of the State. Figure 4 shows that nearly 60 per cent of the hardwood lumber moved to out-of-state outlets. The proportion moving out-ofstate was greatest from the large mills. Large markets were generally unavailable within the State.

Of the 34 million board feet of softwood lumber produced in West Virginia, less than 5 million board feet was marketed out-of-state. The lumber going to out-of-state outlets was marketed mainly in the border states of Virginia, Pennsylvania, Maryland, and Kentucky.

Geographic distribution of hardwood lumber marketed by West Virginia manufacturers is listed by state destination in Table 3. Virginia, North Carolina, Pennsylvania, and Ohio were the most important markets for West Virginia lumber. Percentages shown in Table 3 are based on a total of 217 million board feet of lumber marketed out-of-state. This total does not include the amount of hardwood lumber marketed as unknown in regard to geographical destination, although it is very likely that much of this lumber also follows the pattern shown in Table 3. That

*This study grouped maple and birch into one species group. 


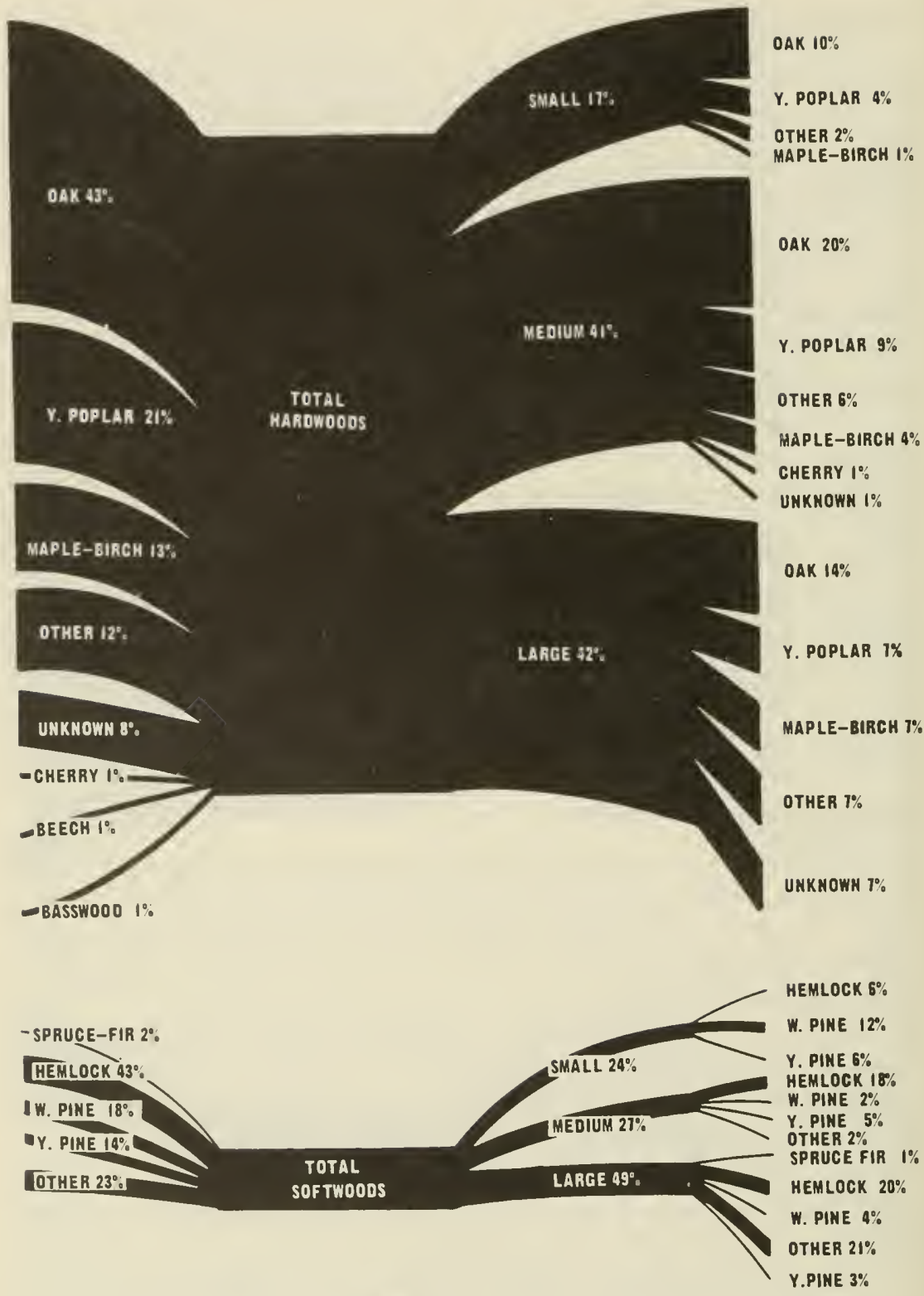

FIGURE 3. Hardwood and softwood lumber marketed by species and mill size.

nearly 40 per cent of the lumber marketed was undesignated as to a specific state suggests that many West Virginia producers did not know the final out-of-state destination of the lumber they sold. 


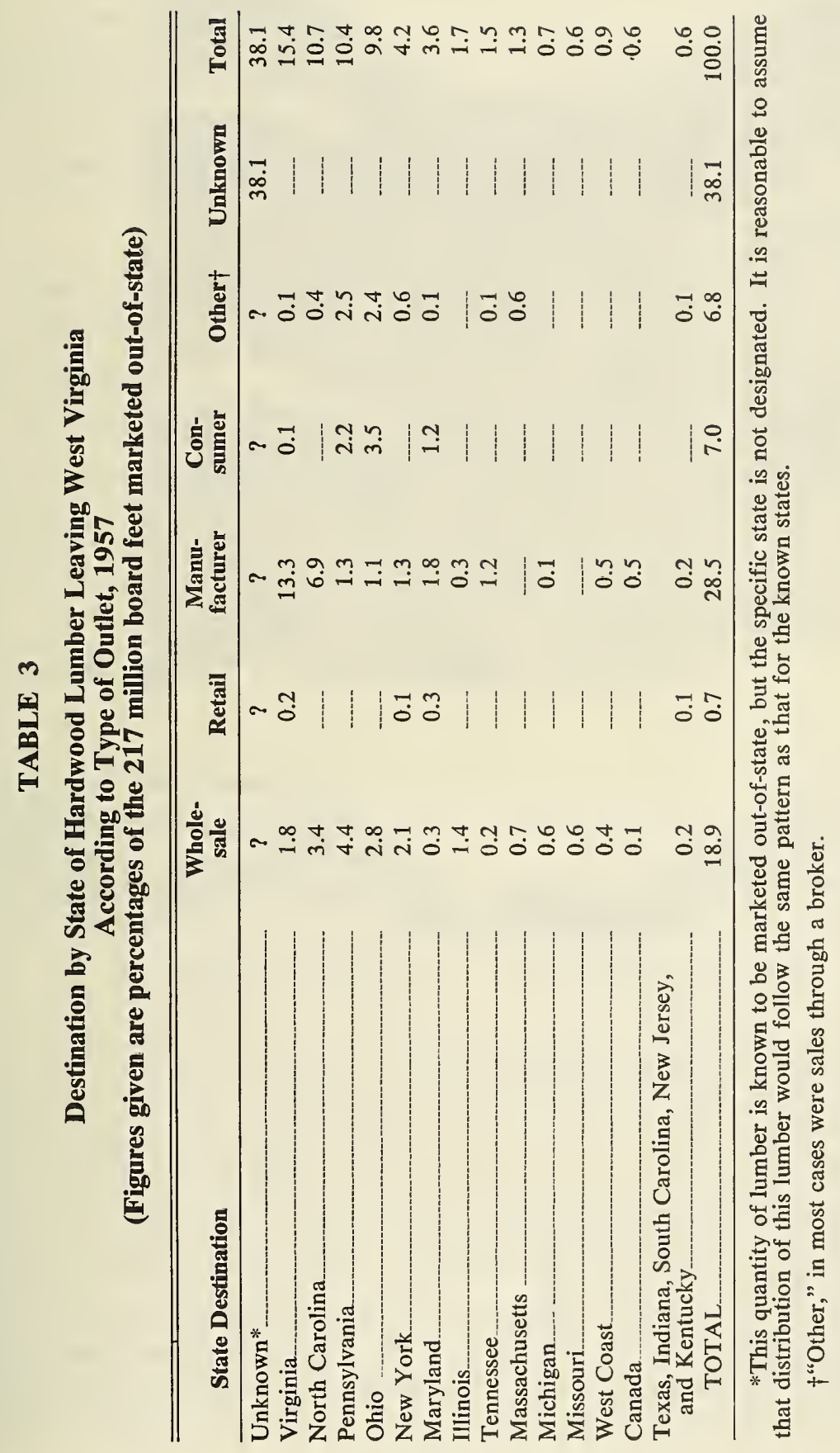




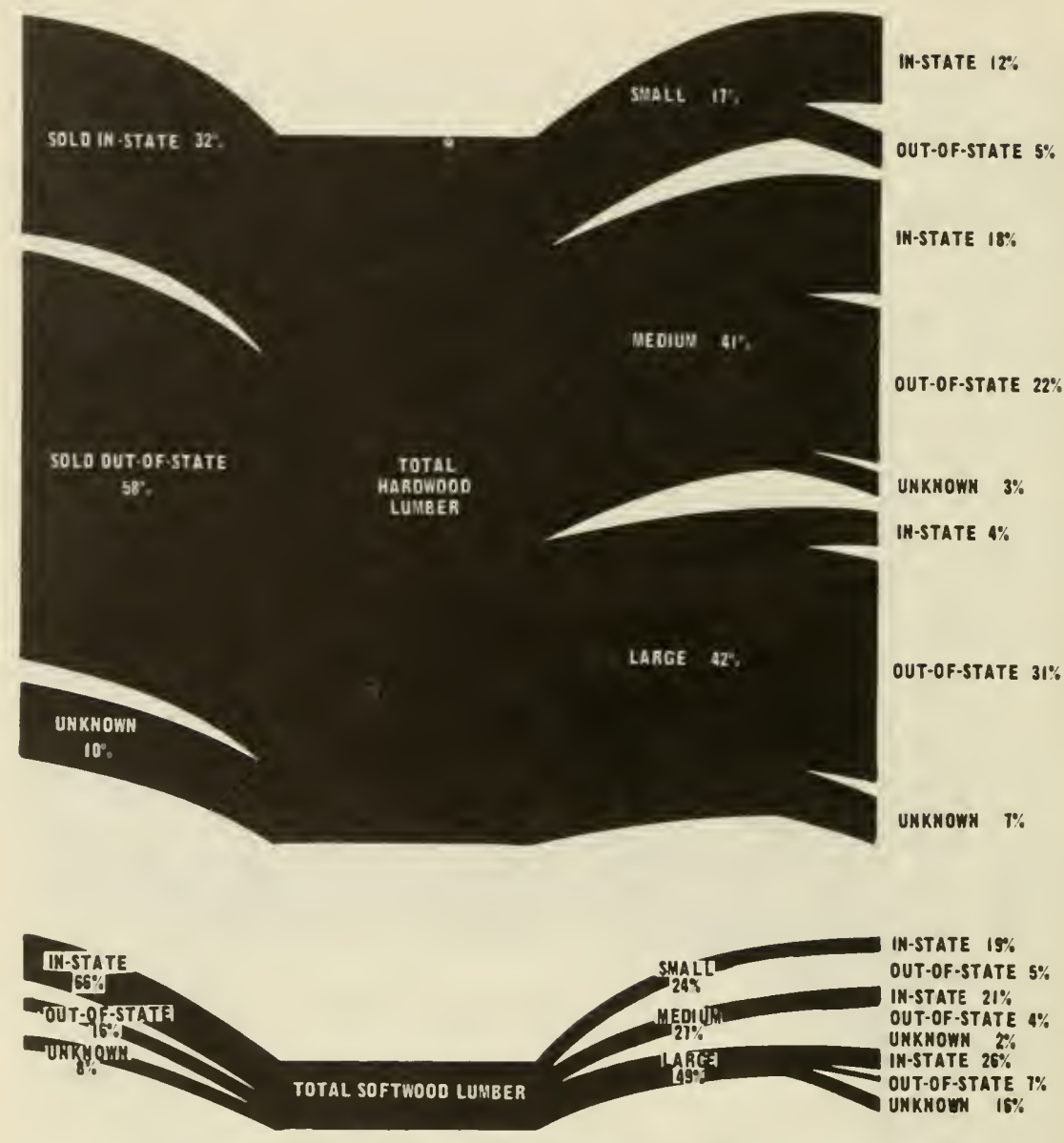

FIGURE 4. Marketing of lumber in-state and out-of-state by size of mill.

Table 3 also reveals that the largest volume of hardwood lumber was marketed directly to manufacturers. It is likely that manufacturers also absorb a large volume of the lumber reportedly sold to wholesalers and handled by brokers. Direct sales to manufacturers in Virginia and North Carolina alone accounted for more than 20 per cent of the out-of-state hardwood shipments. Of the states which border West Virginia, only Kentucky purchased an insignificant volume of West Virginia hardwood.

It is interesting to compare the actual distribution of lumber with a highly theoretical economic model developed by Holland and Judge (1963). By subtracting total consumption from total production, they estimated that West Virginia should have had an excess supply of 225 
million board feet of hardwood lumber in 1958. Then, based upon transportation costs and hardwood lumber deficiencies in surrounding states, they theorized that hardwood lumber should flow from West Virginia to the following states:

\section{5 million board feet to Ohio \\ 40 million board feet to New York}

225 million board feet total hardwood flow from West Virginia

Although the total volume of flow estimated by the model was nearly correct, Ohio and New York were not the states receiving large volumes of West Virginia lumber.

The three states to which most West Virginia lumber actually flows are Virginia, North Carolina, and Pennsylvania. Ohio and New York rank fourth and fifth. The model does not detect the actual flow because it lists Virginia, North Carolina, and Pennsylvania as already having a net surplus of hardwood lumber, therefore, these states would be expected to export rather than import lumber.

The obvious shortcomings of the theory are that individual states are not in themselves economic units. Even though a state's net hardwood lumber production is greater than its net consumption, it may still purchase hardwood lumber from other states. This is true for Pennsylvania, which produces more hardwood lumber than it consumes. Pennsylvania, in turn, markets its excess hardwood lumber primarily in Ohio and New York (Christensen and others, 1962). Thus, some of West Virginia's surplus hardwoods are marketed in Pennsylvania. This enables Pennsylvania to market more surplus hardwoods in Ohio and New York. So the flow determined by the theoretical model actually takes place, although not in as direct a manner as the model indicates.

A major challenge to West Virginia is to become a larger secondary manufacturer of wood products. This would reduce the flow of hardwood lumber from the State, resulting in increased value added by manufacture, greater local employment, and a broader industrial base. From a national and regional outlook, this should be accomplished without transferring unemployment to other states. Luring industry from other areas to West Virginia may help solve the State's problems but not the regional or national problems. Expansion of existing industry already located in West Virginia, expansion by regional or national firms into West Virginia, and the location of new industry within the State are possibly better solutions to the problem of excessive outflow of the State's lumber. 


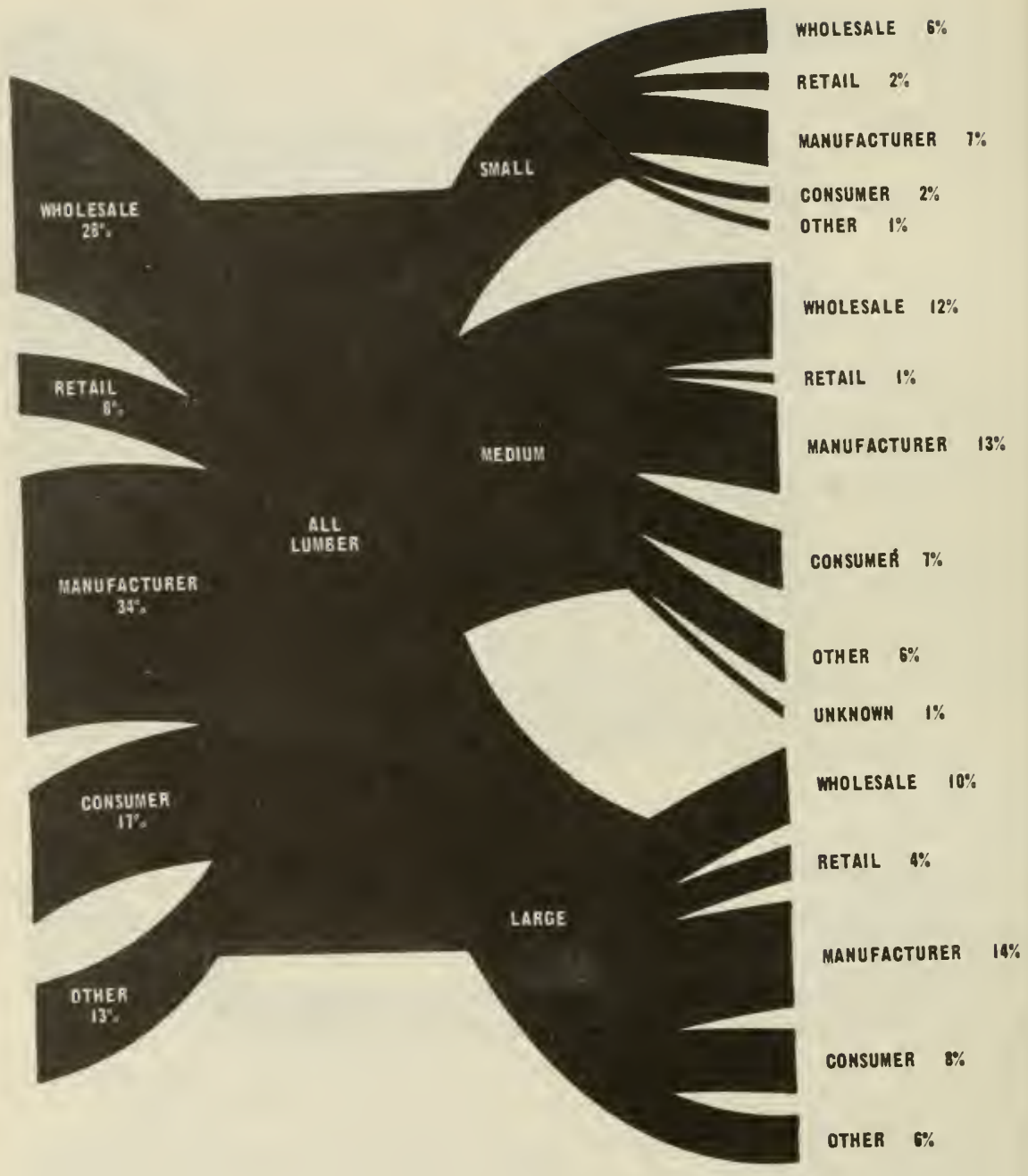

FIGURE 5. Total lumber marketed by type of market outlet and size.

\section{Type of Outlet}

Figure 5 shows the channels through which West Virginia lumber is marketed, combining both hardwood and softwood lumber and in-state and out-of-state outlets.

There appears to be little difference between the size class of firms regarding the type of outlet into which lumber is marketed. The manufacturer was the most important outlet for all size classes, followed by the 


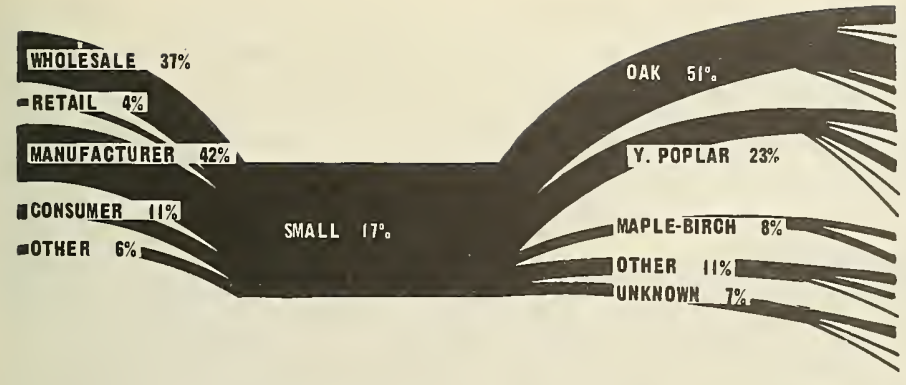

WHOLESALER $13 \%$

RETAILER 2\%

MANUFACTURER $26 \%$

COHSUMER $7 \%$

OTHER 3\%

WHOLESALER $9 \%$

RETAILER $2 \%$

MAHUFACTURER $7 \%$

CONSUMER $3 \%$

OTHER $2 \%$

WHOLESALER $4 \%$

MANUFAGTUREP. $4 \%$

WHOLESALER $6 \%$

MAMUFACTURER 4\%

CONSUMER $1 \%$

WHOLESALER $5 \%$

RETAILER $1 \%$

OTHER $1 \%$
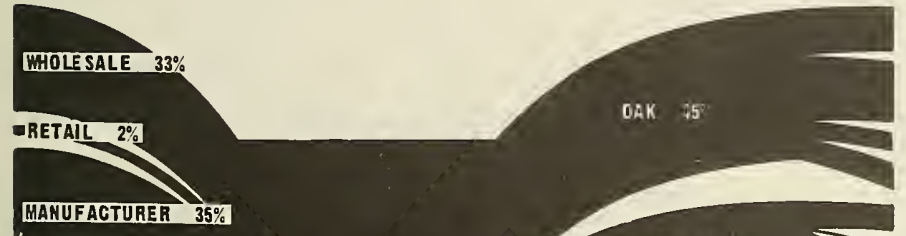

WHOLESALER $14 \%$

MANUFACTURER $20 \%$

CONSUMER $5 \%$

OTHER 7\%

WHOLESALER $8 \%$

RETAILER $1 \%$

MANUFACTURE R $5 \%$

CONSUMER $4 \%$

OTHER $3 \%$

WHOLESALER $4 \%$

MANUFACTURER $2 \%$

CONSUMER $1 \%$

OTHER 2\%

WHOLESALEH $5 \%$

MANUFACTURER $6 \%$

CONSUMER $2 \%$

OTHER 3\%

WHOLESALER $2 \%$

MANUFACTURER 2\%

CONSUAER $2 \%$

UNKNOWH $2 \%$

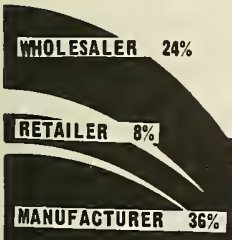

WHOLESALER $5^{\circ}$

RETAILER $2 \%$

MAMUFACTURER $9 \%$

CONSUME R $9 \%$

OTHER 7\%

WHOLESALER 5\%

RETAILER 2\%

MANUFACTURER 6\%

CONSUMER $2 \%$

OTHER $3 \%$

WOLESALLR 5\%

RETAILER 3\%

MANUFACTURER 3\%

CONSUMER $1 \%$

OTHER $4 \%$

WHOLESALER 3\%

RETAILER $2 \%$,

MAHUFACTURER 4\%

CONSUMER $1 \%$

OTHER $3 \%$

WHOLESALER $7 \%$

MANUFACTURER I4\%

FIGURE 6. Outlets for hardwood lumber markefed by size and species.

wholesale outlet. The only large difference was in the larger proportion of lumber marketed to consumers by the medium and large sawmill firms. As shown-in Figure 6, which illustrates the marketing of hardwood lumber by different mill size classes according to outlet and species, the 
wholesale outlet becomes less important for the large sawmills, probably because firms of this size often act as wholesalers. Comparisons among species show that oak lumber was the largest volume item in all three size classes, accounting for over one-half of the total in the small class and about one-third in the large class. The proportion of maple and birch marketed by the large firms, as noted, was considerably greater than for the two smaller size classes.

\section{Grade}

About 15 per cent of the hardwood lumber marketed by West Virginia lumber producers was in the "selects and better" grade (Figure 7 ). Ignoring the lumber of "unknown" grade, a larger proportion of "selects and better" was marketed by the larger firms. Also, the proportion of No. 1 common lumber was greater for these larger firms than for small firms. These large lumber producers also sold a higher proportion of high-grade lumber and, as shown in Figure 4, marketed the highest proportion of hardwood lumber out-of-state. For example, of the 217 million board feet of hardwood lumber sold out-of-state, nearly one-half was in the "selects and better" and "No. 1 common" grades.

Twelve per cent of the hardwood lumber was sold "ungraded." Although Figures 7 and 8 indicate that a high proportion of graded lumber was marketed by mills of all size classes, it is important to recognize that the actual grading was often done by the buyer rather than the seller-especially for sales by the small firms (Figure 11). In effect, the small firm sells lumber ungraded to the buyer, who grades it and pays for it upon the graded price. It is reasonable to assume that in some cases a firm could receive additional revenue by grading lumber prior to selling it.

While the amount of lumber actually sold by the small firms at ungraded prices was fairly low ( 11 million out of 64 million board feet), over one-third of the small mills sold in this manner, thereby tending to reduce their possibilities of receiving higher prices for graded lumber. Although Figure 7 shows that larger firms market a considerable volume of ungraded lumber, this does not typify marketing practices of the large sawmill firms. The ungraded lumber shown for large mills was all produced by one firm. This firm sold the lumber in rough green condition to a specific consumer for a particular end use.

Most of the softwood lumber produced by the smaller firms was of insufficient volume to justify grading. Large firms, however, usually did grade softwood lumber in addition to the hardwood lumber.

A larger proportion of high-grade lumber was marketed through wholesalers than through other outlets, presumably because wholesalers 


\section{Type of Manufacturer}

Thirty per cent of the hardwood lumber marketed in this study was sold directly to manufacturers, and as was pointed out previously, a large proportion initially marketed through other outlets presumably ends up with the manufacturer (Figure 8).

As shown in Figure 9, which illustrates the types of manufacturing

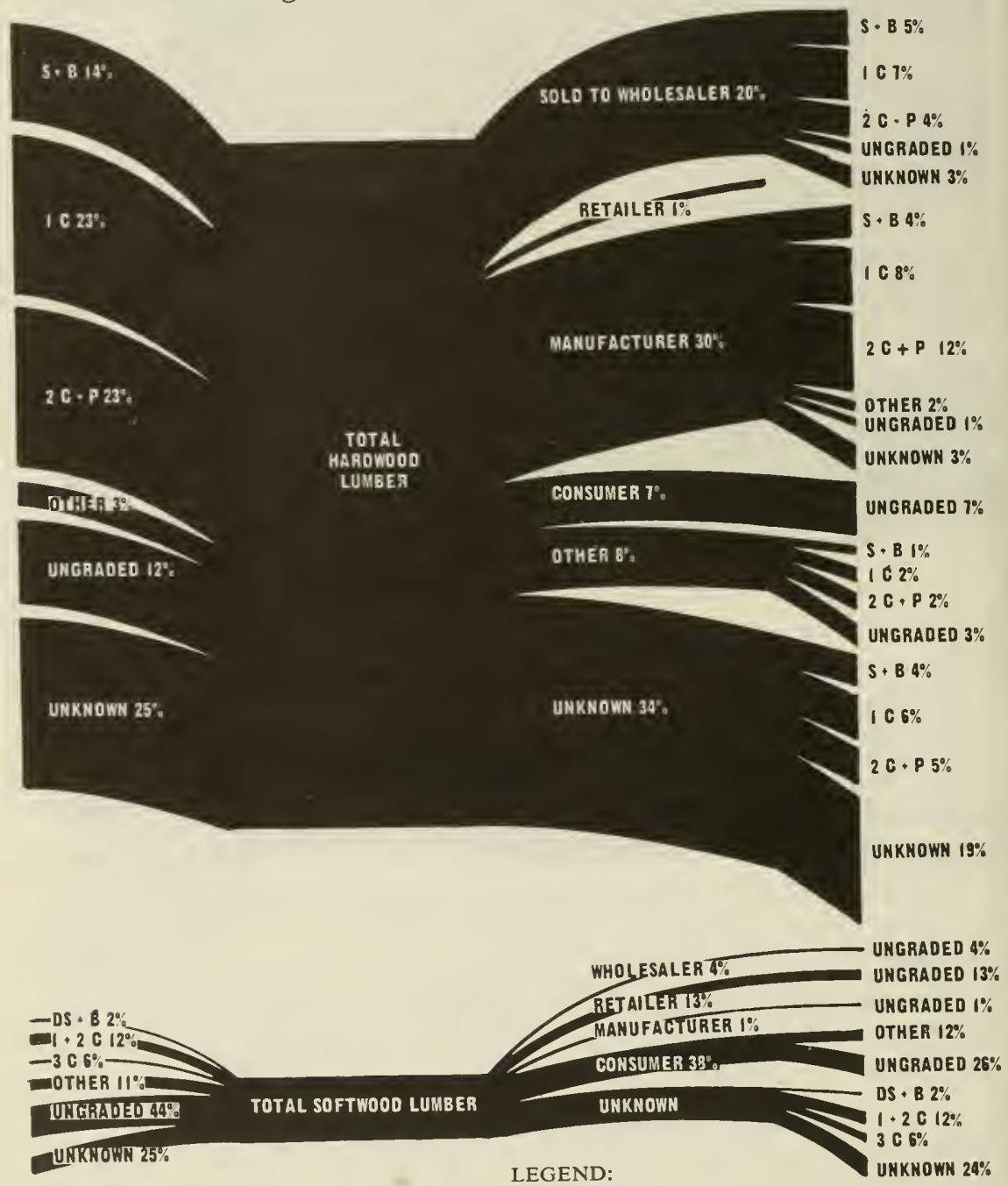
S \& B
Selects and better
D S \& B
D Selects and better
$1 \mathrm{C}$
No. 1 common
$1 \& 2 C$
No. 1 and No. 2 common
$3 \mathrm{C}$
No. 3 common

FIGURE 8. Market outlets for hardwood and softwood lumber by grade and type of outlet. 


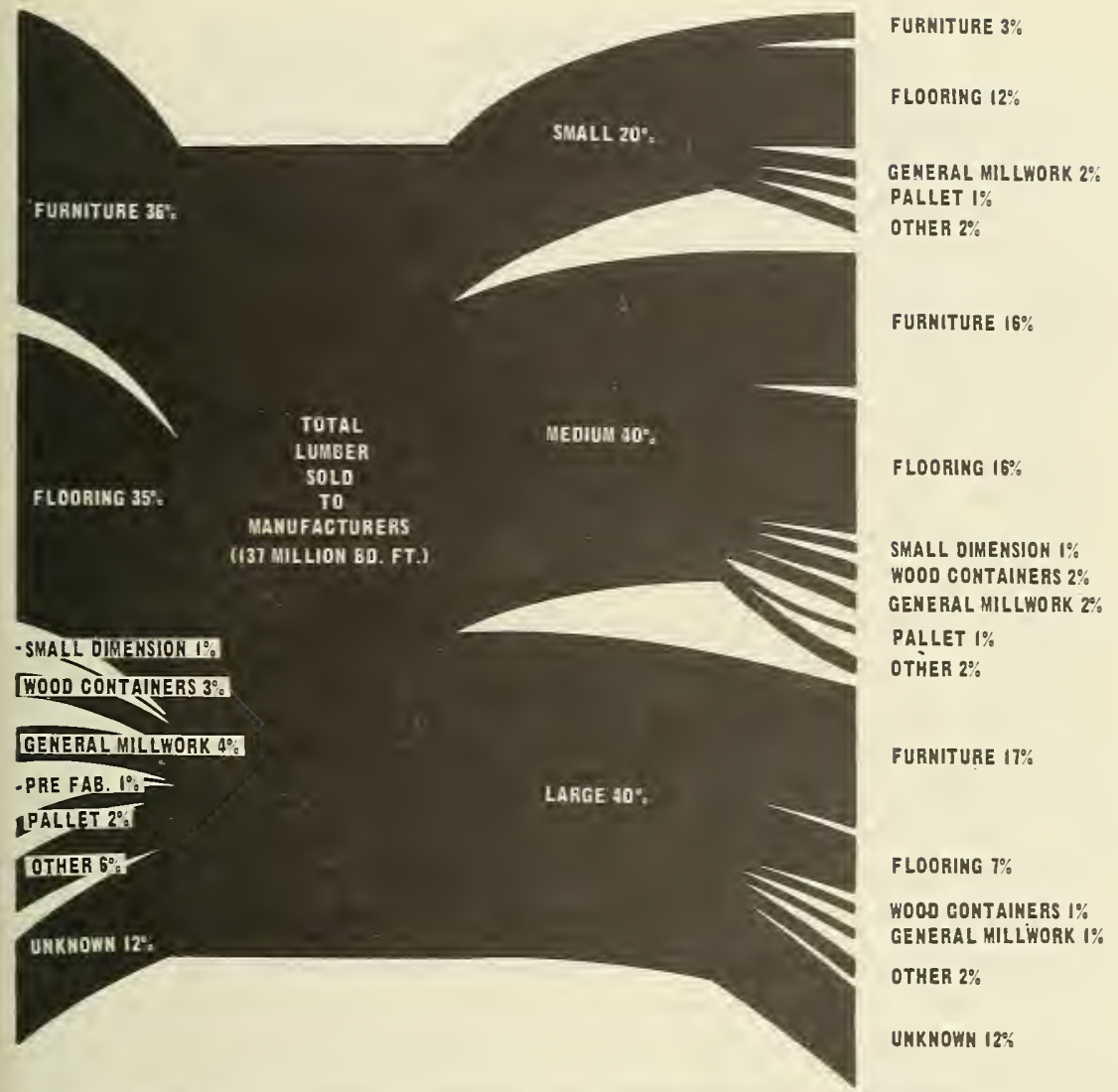

FIGURE 9. Lumber sold to manufacturers by type and size of manufacturer.

outlets into which hardwood lumber flows from West Virginia, furniture and flooring together accounted for over two-thirds of the total. Much of the hardwood lumber sold in-state was manufactured into flooring for which low-grade oak is satisfactory. A large proportion of the highgrade lumber, and considerable maple and birch, was marketed to outof-state furniture manufacturers, principally because West Virginia is not a major furniture manufacturing state.

The relative proportion of lumber marketed to furniture manufacturers increases as the size of the firm increases. Conversely, the relative proportion used for flooring decreases as the size of firm increases. These relationships presumably exist because the large firms not only possess a greater knowledge than the small firms as to the location and variety of out-of-state outlets, but also because the large mills are in a position to satisfy the volume and grade requirements of large out-ofstate manufacturer markets. 


\section{Prices Paid for Lumber Marketed}

The average prices received for lumber, by marketing size class, are listed in Table 4. Included also are the Memphis prices from the Hardwood Market Report (1957) for the same grades and species."

With but one exception (No. 2 common maple-birch), a consistent, upward progression of average price occurred with increasing size of firm. Moreover, only at the large mills did the average price compare closely with the Memphis price.

The differentials in price among mill size classes for the same species and grade of lumber imply that the bargaining position apparently becomes less favorable with decreasing mill size class.

In pure competition, when all producers have a perfect knowledge of all markets, there should be only one price for a given product. In the lumber market, there are many possible reasons for prices to differ. The degree to which prices for the same product diverge may be used as a rough indication of the imperfections of the market. Assuming that no seller is large enough to influence the price, that the product is homogeneoust, and that there are many buyers and sellers who know the price, there should be only one price. If this were true, there would not be as great a need for marketing research.

Table 5 shows that lower prices were received by firms in the smaller mill size-class. Also, firms receiving the lowest prices were normally those which had contacted few or no buyers. It appears that wholesalers actually pay less for lumber on the average, but there are some manufacturers who paid less than some wholesalers. However, over the total range of prices, those paid by manufacturers were considerably above those paid by wholesalers, especially when buying from the small firms. For example, the manufacturer buying FAS oak from firm No. 19 paid $\$ 30.00$ per thousand board feet more than the wholesaler buying the same product from firm No. 7. Both the wholesaler and the manufacturer presumably will tend to buy lumber for as low a price as possible. However, the wholesaler usually is not in a position to pay as high a price as the manufacturer without foregoing some profit, since the wholesaler's existence depends upon the buying of lumber at below market

'A weekly newsletter which reports the selling price of hardwood lumber for reporting mills.

†This homogeneity cannot be assumed in all cases for lumber. One thousand feet of No. 1 common red oak, for example, is not a homogeneous product in that there are various intrinsic and real differences between similar units as produced by different sawmills. Such factors as color, texture, grain, uniformity of growth, specific gravity, region of growth, and others may cause price differences between what, on paper, is the same product. In this case, there may be a real difference in value. 
TABLE 4

Prices Paid for Lumber Marketed by Marketing Size Class

F.O.B. Price in Dollars per M Board Feet-Based on Rough Air-dried, 4/4 Lumber

\begin{tabular}{lcccc}
\hline \hline \multicolumn{1}{c}{ Species Group and Grade } & $\begin{array}{c}\text { Small } \\
\text { (Dollars) }\end{array}$ & $\begin{array}{c}\text { Medium } \\
\text { (Dollars) }\end{array}$ & $\begin{array}{c}\text { Large } \\
\text { (Dollars) }\end{array}$ & $\begin{array}{c}\text { Memphis } \\
\text { Price* } \\
\text { (Dollars) }\end{array}$ \\
\hline Oak-FAS & 140 & 167 & 209 & $200-220$ \\
Oak-No. 1 Common & 86 & 96 & 116 & $115-120$ \\
Oak-No. 2 Common - & 56 & 59 & 68 & $67-67$ \\
Yellow Poplar-FAS & 146 & 167 & 204 & 200 \\
Yellow Poplar-No. 1 Common & 90 & 103 & 131 & 132 \\
Maple-Birch-FAS & 181 & 210 & 250 & $240-270$ \\
Maple-Birch-No. 1 Common - & 113 & 128 & 153 & $150-165$ \\
Maple-Birch-No. 2 Common-- & 61 & 59 & 70 & $75-105$ \\
Cherry-FAS & 216 & 247 & 278 & 270 \\
Cherry-No. 1 Common & 136 & 158 & 185 & 185 \\
Cherry-No. 2 Common & 62 & 76 & 100 & 95 \\
\hline
\end{tabular}

*From Hardwood Market Report, Lumber News Letter. Vol. XXXV, No. 38, Sept. 21, 1957, Memphis Tenn., p. 4, Appalachian Hardwoods.

price, and then re-selling to manufacturers at a price near to the market price. The manufacturer should be able to pay a price approximating that of the market, whether buying from lumber producers or from wholesalers.

The data shown in Table 5 contain some bias since each firm marketed all of its lumber through a single channel. Therefore, the price received was likely to be below normal because the firm apparently did not have the alternative of selling through other channels. For example, firm No. 20 sold No. 1 common oak to wholesalers for $\$ 50.00$ per thousand board feet. This price is $\$ 65.00$ to $\$ 70.00$ less than the Memphis price, and $\$ 25.00$ per thousand less than the price received for the same product by another firm listed in Table 5. Also, no other buyers were contacted by this firm. The interview with this firm revealed that no time was spent finding markets, and lumber was sold as soon as someone offered to buy it.

\section{Effect of Grading and Marketing Effort Upon Price}

Despite a great difference in price between grades, as shown in Tables 4, 5, and 6, some mills still sell ungraded lumber. Small firms receive an average price of $\$ 97.00$ per thousand board feet for graded lumber and $\$ 60.00$ per thousand board feet for ungraded lumber. The average price paid for ungraded lumber was actually lower than the 
TABLE 5

Prices Received by Producers, and Number of Buyers Contacted, for Those Producers Who Sold Their Total 1957 Production to Either

Wholesalers or to Manufacturers

(Price in Dollars per $1 \mathrm{M}$ bd. ft., air-dried, F.O.B. Mill)

\begin{tabular}{|c|c|c|c|c|c|c|}
\hline \multirow{2}{*}{$\begin{array}{l}\text { Size of Firm } \\
\text { and Number }\end{array}$} & & \multicolumn{3}{|c|}{ FAS Oak } & \multicolumn{2}{|c|}{ No. 1 Common Oak } \\
\hline & & $\begin{array}{l}\text { Number of } \\
\text { Buyers } \\
\text { Contacted* }\end{array}$ & $\begin{array}{l}\text { Whole- } \\
\text { salers } \\
\text { Price }\end{array}$ & $\begin{array}{c}\text { Manufac- } \\
\text { turers } \\
\text { Price } \dagger\end{array}$ & $\begin{array}{l}\text { Whole- } \\
\text { salers } \\
\text { Price } \dagger\end{array}$ & $\begin{array}{c}\text { Manufac- } \\
\text { turers } \\
\text { Price } \dagger\end{array}$ \\
\hline \multicolumn{7}{|l|}{ Small Firms } \\
\hline \multirow[t]{22}{*}{ Firm No. } & & 0 & 110 & --- & 80 & - \\
\hline & 2 & 0 & 115 & $\ldots$ & 75 & - \\
\hline & $\begin{array}{l}3 \\
4\end{array}$ & $\begin{array}{l}3 \\
2\end{array}$ & $\begin{array}{l}135 \\
135\end{array}$ & -- & $\begin{array}{l}80 \\
90\end{array}$ & $\overline{-}$ \\
\hline & $\begin{array}{l}4 \\
5\end{array}$ & 17 & 150 & 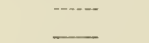 & 90 & $\cdots$ \\
\hline & 6 & 10 & 150 & $\overline{-}$ & 80 & $\ldots$ \\
\hline & 7 & 7 & 150 & $\ldots$ & 85 & $\ldots$ \\
\hline & 8 & 4 & $\ldots$ & 95 & --- & 85 \\
\hline & 9 & 6 & $\ldots$ & 125 & - & 70 \\
\hline & 10 & 3 & $\ldots$ & 125 & $\ldots$ & 90 \\
\hline & 11 & 5 & $\ldots$ & 125 & $\ldots$ & 90 \\
\hline & 12 & 15 & $\ldots$ & 130 & --..- & 80 \\
\hline & 13 & $\ldots$ & - & 132 & $\ldots$ & 82 \\
\hline & 14 & 2 & - & 135 & - & 87 \\
\hline & 15 & $-\ldots$ & - & 140 & $\ldots$ & 75 \\
\hline & 16 & $\ldots$ & ---- & 150 & $\ldots$ & \\
\hline & 17 & 24 & - & 167 & $\ldots$ & 92 \\
\hline & 18 & 4 & ..--- & 170 & $\ldots$ & 105 \\
\hline & 19 & 7 & - & 180 & $\bar{\square}$ & 100 \\
\hline & 20 & 0 & - & $\ldots$ & 50 & - \\
\hline & 21 & 0 & $\cdots$ & - & - & - \\
\hline & 22 & $\begin{array}{l}0 \\
0\end{array}$ & ---- & - & --- & $\cdots$ \\
\hline & $\begin{array}{l}23 \\
24\end{array}$ & 4 & $\overline{-}$ & $\overline{-}$ & n............. & $\ldots$ \\
\hline \multicolumn{2}{|c|}{ Average Price } & & 135 & 140 & 79 & .87 \\
\hline \multicolumn{7}{|c|}{ Medium-Sized Firms } \\
\hline \multirow[t]{4}{*}{ Firm No. } & 25 & 1 & 160 & & 80 & \\
\hline & 26 & 2 & $\ldots$ & 135 & 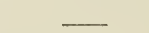 & 87 \\
\hline & 27 & 0 & _.. & 150 & $\ldots$ & 95 \\
\hline & 28 & 5 & $\ldots$ & - & - & - \\
\hline \multicolumn{2}{|c|}{ Average Price } & & 160 & 142 & 80 & 91 \\
\hline \multicolumn{7}{|l|}{ Large Firms } \\
\hline \multirow[t]{2}{*}{ Firm No. } & 29 & 12 & 165 & $\ldots$ & 90 & …-- \\
\hline & 30 & 275 & 210 & $\ldots$ & 120 & - \\
\hline \multicolumn{2}{|c|}{ Average Price } & & 188 & --- & 105 & - \\
\hline \multicolumn{2}{|c|}{ Memphis Price } & & \multicolumn{2}{|c|}{$200-220$} & \multicolumn{2}{|c|}{$115-120$} \\
\hline
\end{tabular}

$\$ 60.00$ per thousand board feet for the medium and large firms, which reflects the "picking over" which had probably taken place. This represents a lower real value for the products rather than a weaker competitive position. A small firm which markets all lumber ungraded normally will 
TABLE 5 (Contd.)

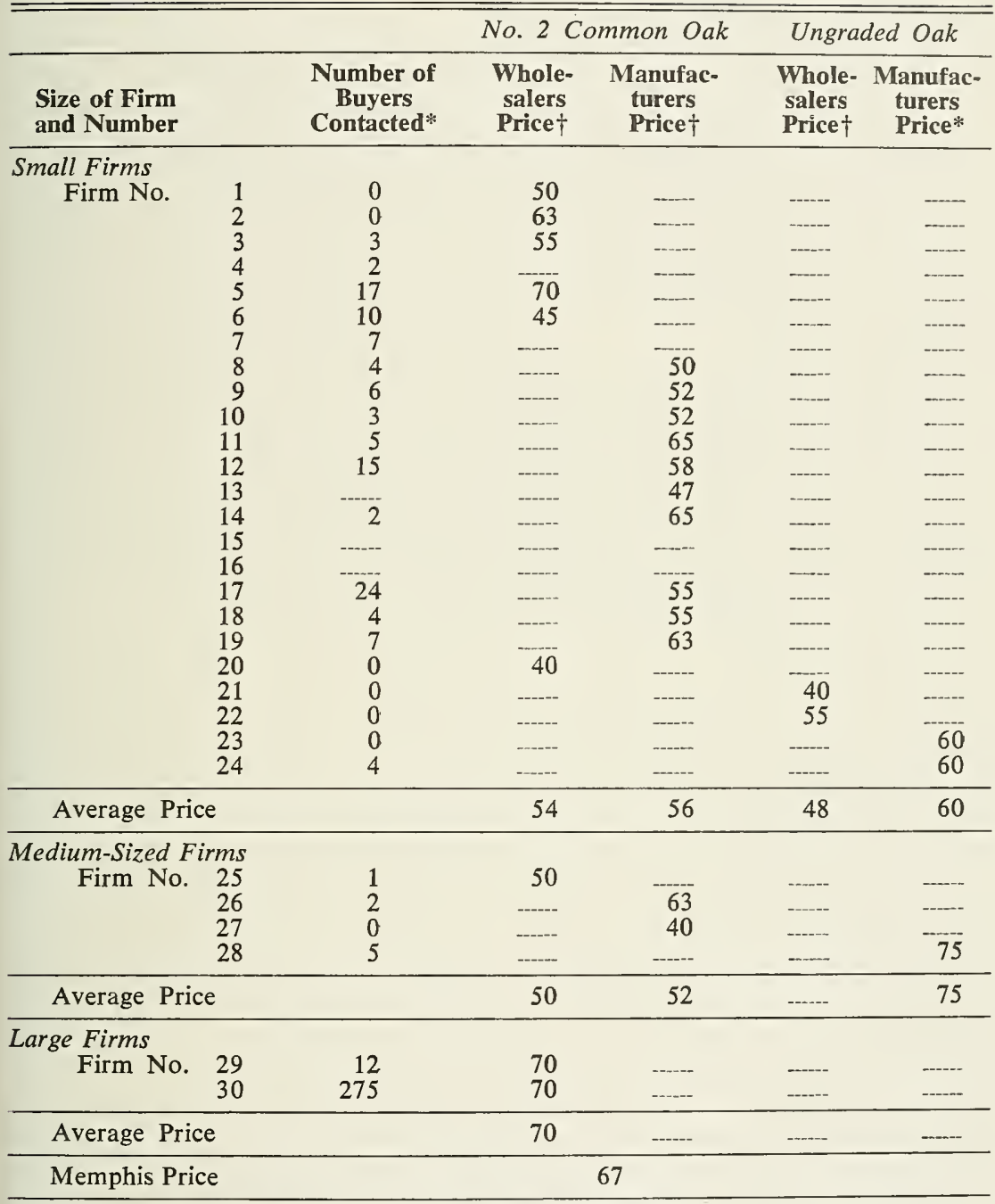

*Does not include the number of customers contacted.

$\dagger$ Dollars.

have some high-quality lumber mixed in. A large firm which grades most of its lumber will not usually sell ungraded lumber containing high-grade boards, but will remove the high-grade material first. The medium-sized firms received an average price for all graded lumber of $\$ 114$ per thousand board feet and the large firms received $\$ 134$ per thousand board feet. This indicates that small firms selling ungraded lumber for $\$ 60.00$ per thousand board feet would, with a more favorable 
market situation, sell the same lumber graded for about twice the price, assuming that the grade recovery in sawing resulted in approximately the same proportion of grade lumber.

It would seem reasonable to expect that as a firm spent more time in searching out markets for lumber, some increase in average lumber price received would occur. This relationship is implied in Table 6, and indicates that the prices approached the Memphis price with increasing time spent searching out markets. However, the data shown in Table 6 should not be construed to automatically mean that any producer who spends over 40 hours per month to find markets will be able to sell at prices near the market price, because other factors also enter into price as, for example, the difference in marketing skills and in knowledge of marketing prices. For example, one producer in this survey spent 53 hours per month marketing 940,000 board feet of lumber. He sold most of his lumber through wholesalers. His marketing effort consisted of contacting about 25 of these wholesalers. As a result, he received $\$ 190$ per thousand board feet for FAS oak and $\$ 100$ per thousand board feet for No. 1 common. These prices approach the Memphis price. Another producer with a similar lumber volume and marketing effort, also contacted 25 wholesalers. He received $\$ 125$ per thousand board feet for FAS oak and $\$ 75.00$ per thousand board feet for No. 1 common. In these cases, the producer receiving the higher price sold his entire production based on an established market price, whereas the producer receiving the lower price sold his total production at a price established by the buyer of the lumber. In every case, in Table 6, the average price received under marketing effort of "over 40 hours" was greater than the price under the "1-to-10 hour" category.

\section{Bargaining Position}

One indication of the relative bargaining position of firms is the basis upon which prices are determined. As shown in Figure 10, a majority of small and medium firms in this survey sold their lumber at a price established by the buyer, whereas most of the large firms sold their lumber for the seller's price. A compromise price was common only in the medium units which apparently are large enough to attract the competition of several buyers, but not large enough to set the price. The market price was fairly common in the large and medium mills, but not in the small mill-class.

It would seem logical that the price offered by the buyer would be the lowest price received by those selling lumber; the market price and the seller's prices would be the highest, and the compromise price would fall some place in between. This relationship was tested by using 


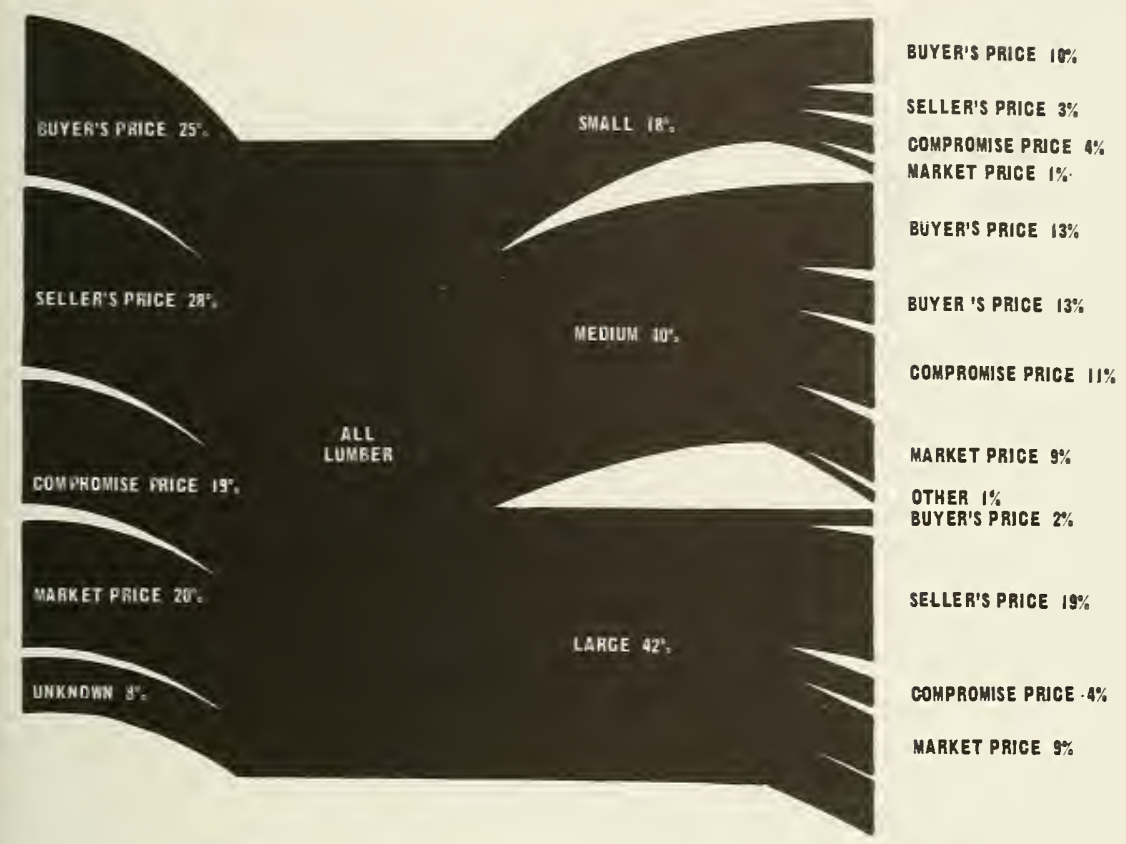

FIGURE 10. Price basis for lumber marketed by marketing size class.

the firms in the survey which sold their total volume based on a buyer's price, a seller's price, a compromise price, or a market price. The firms which sold entirely on the buyer's price received an average of \$141 per thousand board feet for FAS oak. The firms which sold on a compromise price received an average of $\$ 161$ per thousand board feet, and those selling their entire volume for a market price averaged $\$ 188$ per thousand board feet for the same species and grade of lumber. A few firms which sold exclusively at their own (i.e., seller's) price received an average of $\$ 172$ per thousand board feet. Of course, many other firms sold part of their lumber at a compromise price, part at market price, and part at seller's price. However, in general, the assumption that market price and seller's price will be highest seems to be valid. The problem of the small firm appears to be one of obtaining sufficient bargaining power to demand the market, or the seller's price, for a relatively small volume of lumber sales.

\section{Method, Type, and Terms of Sale}

The most common sales method for all size classes was sale from stock. For the small firms, almost one-third of the lumber marketed was sawn after the order, but this proportion decreased to 10 per cent for the large firms. 
TABLE 6

Prices Paid for Lumber Marketed by Time Spent Finding Markets F.O.B. Prices in Dollars per $1 \mathrm{M}$ bd. ft.-Based on Rough, Air-dried, 4/4 Lumber

(Time spent finding market in hours per month)

\begin{tabular}{|c|c|c|c|c|c|}
\hline Species Group and Grade & $\begin{array}{c}0 \\
\text { Hrs. }\end{array}$ & $\begin{array}{l}1-10 \\
\text { Hrs. }\end{array}$ & $\begin{array}{l}10-40 \\
\text { Hrs. }\end{array}$ & $\begin{array}{l}\text { Over } \\
40 \text { Hrs. }\end{array}$ & $\underset{\text { Price* }}{\text { Memphis }}$ \\
\hline & \multicolumn{5}{|c|}{ Dollars } \\
\hline Oak-FAS & 136 & 163 & 162 & 197 & $200-220$ \\
\hline Oak-No. 1 Common . & 85 & 90 & 91 & 120 & $115-120$ \\
\hline Oak-No. 2 Common & 51 & 60 & 56 & 65 & $67-67$ \\
\hline Yellow Poplar-FAS & 138 & 157 & 160 & 194 & 200 \\
\hline Yellow Poplar-No. 1 Common & 80 & 103 & 102 & 123 & 132 \\
\hline Maple-Birch-FAS & 174 & 197 & 207 & 225 & $240-270$ \\
\hline Maple-Birch-No. 1 Common & 107 & 122 & 127 & 134 & $150-165$ \\
\hline Maple-Birch-No. 2 Common & 51 & 62 & 60 & 65 & $75-105$ \\
\hline Cherry-FAS & 160 & 231 & 252 & 255 & 270 \\
\hline Cherry-No. 1 Common & 110 & 146 & 167 & 167 & 185 \\
\hline Cherry-No. 2 Common & -.-. & 66 & 77 & 83 & 95 \\
\hline
\end{tabular}

*From Hardwood Market Report, Lumber News Letter. Vol. XXXV, No. 38, Sept. 21, 1957, Memphis, Tenn., p. 4, Appalachian Hardwoods.

Cash sales were used most often, with payment requested within 30 days. Over 90 per cent of the sales was for cash. There were a few sales on consignment, bill-of-exchange, and deferred settlement. No forward selling or future contracts were recorded.

Terms of sale, as used here, refers to agreements between buyer and seller. Most sellers marketed lumber by a variety of agreements. The most common sales agreement was for the seller to deliver a specified quantity of lumber at intervals as requested by the buyer; however, only 10 per cent of sales was on this basis. Several firms agreed to sell their total production for a specified period of time to a given buyer. Of the several firms which had this agreement, some sold their total production year after year to the same buyers, while others entered this agreement for shorter periods of time.

\section{Reasons for Selling to Buyers}

The sellers in this study were confronted with a list of 12 reasons why they might sell to a certain buyer. They were asked to rate their reasons numerically: $1,2,3$, etc., according to the most important reason. Table 7 summarizes the information gathered, according to frequency with which any one reason was given, and according to frequency with which a reason was listed as the most important. 
TABLE 7

Reasons for Selling to Buyers as Given by Firms Surveyed

\begin{tabular}{|c|c|c|c|c|c|c|}
\hline \multirow[b]{2}{*}{ Reason } & \multicolumn{2}{|c|}{ Small Firms } & \multicolumn{2}{|c|}{ Medium-Size Firms } & \multicolumn{2}{|c|}{ Large Firms } \\
\hline & $\begin{array}{c}\text { Listed } \\
\text { as most } \\
\text { impor- } \\
\text { tant }\end{array}$ & $\begin{array}{l}\text { Total } \\
\text { times } \\
\text { listed }\end{array}$ & $\begin{array}{c}\text { Listed } \\
\text { as most } \\
\text { impor- } \\
\text { tant }\end{array}$ & $\begin{array}{l}\text { Total } \\
\text { times } \\
\text { listed }\end{array}$ & $\begin{array}{c}\text { Listed } \\
\text { as most } \\
\text { impor- } \\
\text { tant }\end{array}$ & $\begin{array}{l}\text { Total } \\
\text { times } \\
\text { listed } \\
\end{array}$ \\
\hline Best Price Offered & 28 & 44 & 17 & 23 & 1 & 4 \\
\hline $\begin{array}{l}\text { Buyer Pays Cash Upon Delivery-- } \\
\text { Buyer Pays Cash Within a }\end{array}$ & 7 & 32 & 2 & 19 & --- & 1 \\
\hline Certain Time Period & 2 & 8 & 2 & 9 & --- & 2 \\
\hline $\begin{array}{l}\text { Buyer Comes to the Mill } \\
\text { Long-Standing Business }\end{array}$ & 4 & 11 & 1 & 6 & $\ldots$ & 1 \\
\hline Connection & 6 & 17 & 7 & 17 & $\ldots$ & 4 \\
\hline Companies' or Buyers' Reputation & 5 & 21 & 8 & 21 & 5 & 5 \\
\hline Buyer Purchases on Grade & 1 & 6 & 1 & 8 & 1 & 2 \\
\hline Buyer Will Take All Grades & 4 & 16 & - & 2 & $\ldots$ & 1 \\
\hline $\begin{array}{l}\text { Can Usually Sell to Buyer } \\
\text { When Market is Poor }\end{array}$ & 2 & 15 & 1 & 10 & - & 1 \\
\hline Friendship with Buyer & $\ldots$ & 2 & $-\ldots$ & $\cdots$ & $\ldots$ & $\ldots$ \\
\hline Only Buyer Known & 2 & 2 & - & 1 & $\ldots$ & $\ldots$ \\
\hline 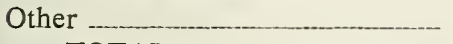 & 4 & 12 & 2 & 3 & $\ldots$ & $\ldots$ \\
\hline TOTAL _ & 65 & 186 & 41 & 119 & 7 & 20 \\
\hline
\end{tabular}

The most important reason for selling to certain buyers given by the small and medium firms was that they offered the best prices. In contrast, the buyer's reputation was the reason given most often by the large firms. A buyer who pays cash upon delivery was rated as the next most important reason for selling to a certain buyer by the small firms, a consideration not so important to the larger firms. Small- and medium-size firms listed long-standing business connections and buyer's reputation as other important reasons. Some small mills sold to a particular buyer because he would come to the mill, or because he would take all grades. A reason often listed by small mills was that they could usually sell to this buyer when markets are poor, therefore, they sell to him when markets are good to protect this advantage.

\section{Grade and Volume Determination}

Lumber is sold by grade and by board foot volume of the individual boards. Determination of these is the function of the lumber grader. The hardwood lumber is graded by National Hardwood Lumber Association rules. With the exception of the small amount of lumber sold by special grades, listed as "other" in Figures 7 and 8, the major volume is graded and measured by Association rules. For the protection of 
buyers and sellers the Association has a re-inspection clause, whereby any buyer or seller may contest the grade or volume as determined by the grader. The Association will then re-inspect the lumber, and if an actual mistake has been made, the necessary adjustments between buyer and seller will be made.

Figure 11 shows, by marketing size class, who measures and grades the lumber marketed by West Virginia producers. As indicated, most of the lumber marketed by the small firms and a large volume of lumber marketed by the medium firms is measured and graded by the buyer's grader, who is often a non-certified grader. This places these firms at a disadvantage in that they sell on the basis of grade and volume as determined by the buyer. Of course, the seller can always contest the grade and volume determination, but this is risky, since the entire cost of Association regrading is borne by the contesting firm, if the grade is upheld.

Almost all of the lumber sold by the large marketing units is sold on the seller's grade determination. This is more likely to represent the true grade and volume of the lumber, especially since much of this is graded by certified Association graders. In most cases, the buyer will regrade some or all of the lumber as a check on the seller's grader, and this may result in a dispute in which the Association becomes an arbitrator.

\section{Inventory on Hand}

The primary reasons for holding inventories of lumber are to add value by air drying, to accumulate a marketable quantity, and to wait for more favorable market conditions. The firms, in this study were asked to give their minimum and maximum yard stocking, and the basis used for determining the maximum volumes of inventory they would carry. No distinction is intended here between inventory and yard stocking although the process of air drying, which ties up large volumes of lumber in the yard, could conceivably be considered as a final step in processing rather than a part of the inventory.

Small firms listed an average of 13,000 board feet minimum and 62,000 board feet maximum yard stocking. Over two-thirds of these firms, however, allowed inventories to drop to zero sometime during the year. The basis for determining the volume of inventory a firm could carry was obtained by asking an open-end question. For most of the small firms, capital limitations were said to govern inventories. A common answer given was, "I sell green lumber to avoid tying up capital in my drying yard." One producer indicated that he sold green lumber because he 


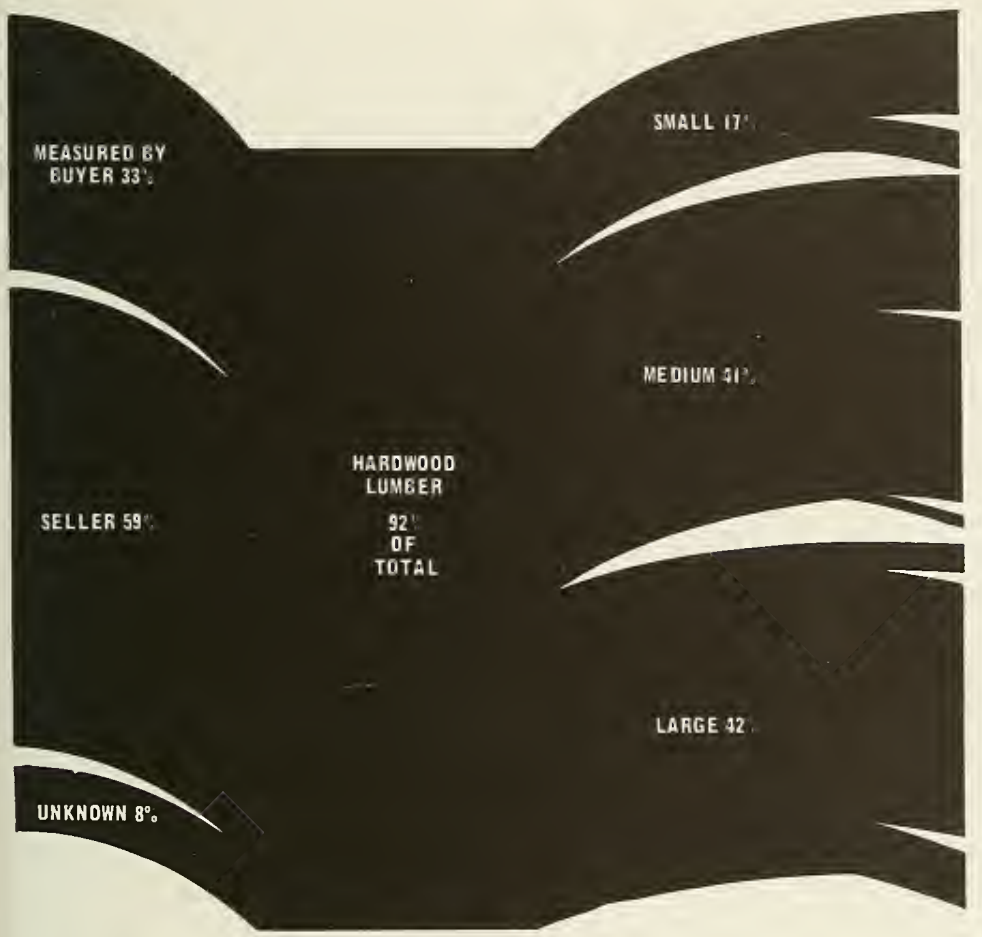

BUYER $13 \%$

SELLER $4 \%$

BUYER $17 \%$

SELLER $23 \%$

UNKNOWN $1 \%$ BUYER 3\%

UNKNOWN $7 \%$

\section{MEASURED BY}

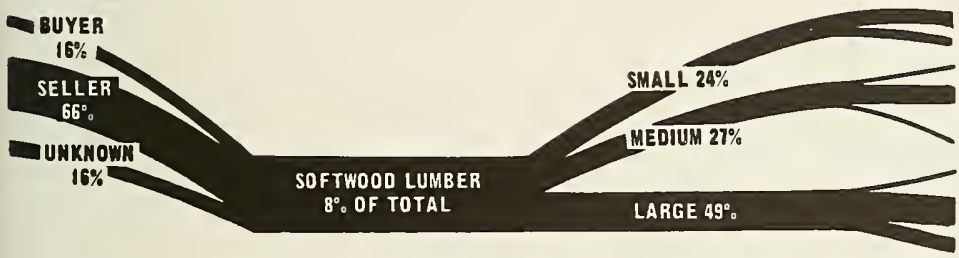

BUYER $13 \%$ SELLER $11 \%$ BUYER $2 \%$ SELLER $24 \%$ UNKNOWN $1 \%$ BUYER I\% SELLER 32\% UNKNOWN $16 \%$

FIGURE 11. Proportion of lumber measured by buyer, seller, or unknown by size class.

needed money for the payroll. Another said, simply, "A little man can't carry it." Another common method of determining inventory for this small-size class was based on local market conditions if the price offered was too low, the lumber was kept in inventory until the price improved, or until the firm was forced to sell in order to pay operating costs. Some producers indicated an insufficient price difference between green and air-dried lumber to justify holding lumber in stock for yard drying. Other firms, which considered air-drying profitable, indicated that the volume held in their yard stocks was determined by how long it took the lumber to air-dry, which depends upon the season and species. 
Medium-size firms held an average of 233,000 board feet inventory minimum, and 582,000 board feet maximum. Only 20 per cent of these firms allowed their inventories to drop to zero. The maximum yard stocking was determined primarily by market conditions and the space available in the yard. Capital was also a factor; several producers indicated that the maximum yard stocking was reached when the money in their personal bank account dropped to a certain low balance.

The inventories of large firms ranged from a low of 3.5 million board feet to a high of almost 7 million board feet. All of the firms maintained substantial inventories. Market conditions formed the basis for determining the maximum yard stocks to be held by most firms. Under favorable market conditions, inventories would fall toward the minimum. The firm would then increase production by adding a shift, by overtime, or by an extra workday per week. If market conditions were unfavorable, inventories would rise toward the maximum, and the firm would respond by slowing down production.

One firm indicated that during the unfavorable marketing conditions of the depression years, over 30 million board feet of lumber were held in the yard. This was equal to the total production of several years. Obviously, only a firm with large capital reserves could weather such market conditions. The average price of oak in West Virginia in 1928 was over $\$ 46.00$ per thousand board feet. By 1932 this price had fallen to $\$ 32.00$ per thousand board feet, and it remained low until 1941 (Steer, 1948).

Small firms that lack the capital needed to hold large inventories are placed at a marketing disadvantage. The producer who needs to sell green lumber to pay wages is not in a favorable bargaining position. This producer was forced to sell all species for the same price- $\$ 135$ per thousand board feet for FAS grade. Although he marketed a considerable proportion of the higher priced species such as yellow-poplar, maple, birch, and basswood, he received less than the average price received by the small firms for oak, as given in Table 4 . 


\section{Conclusions}

The data presented in this study underscore the relatively weak market position of small sawmill owners in West Virginia. These owners often lack knowledge of markets for their lumber and generally must accept buyers' estimates of lumber volume and grade, as well as buyers' prices. This condition is further compounded by lack of capital resources of a majority of the small mills.

Assuming that small sawmills continue to exist, although probably in decreasing numbers over time, the question arises as to what action can be taken to strengthen their relative position in the lumber market. Possibly the first step should be in the direction of education, i.e., providing such mill owners with information on the various existing markets for their lumber and the prices being paid in these markets. Such information is necessary for the decision-making process-the less informed the seller, the less the possibility of his making the most profitable decision regarding the marketing of his product.

Whitmore concludes a Northeastern regional lumber marketing study by pointing out that the large firms are able to spend more time and money on marketing activities. This segment of the industry is therefore closer to the ideal market situation than the segment which does not seek out markets. "A free economy does not function properly when market information is lacking on the part of the buyer or seller. Therefore, it would seem to be a legitimate function of marketing research to make information available, particularly to the small producer, if for no other reason than to convince him that perhaps he is not a competitive unit. This would furnish an incentive for some types of integration or cooperative marketing" (Whitmore and others, 1963).

General recommendations as to production and marketing of the maximum amount of grade lumber are difficult to make without further research. For example, it is possible that small producers may maximize profits by selling all lumber on a mill-run basis. By so doing, the extra costs of sawing, grading, sorting, and handling, and the costs of holding capital (particularly low-grade lumber) are not incurred. On the other hand, it is possible that the additional returns resulting from grading may sufficiently offset the additional costs, providing a higher net return to the operator. Questions such as these suggest areas in which future research might provide fruitful results.

During the survey, an almost universal complaint was made by mill owners producing and marketing lumber for grade-the difficulty of 
selling, at a profit, the lower grades of lumber (No. 2 common and poorer for hardwoods and No. 3 common and poorer for softwoods). It is likely that this particular problem will continue until such time as new markets are created for low-quality lumber. And this, again, suggests the potential contribution of further research, not only on profitable utilization of low-grade lumber but also in the area of new wood-product development, particularly new products which can be manufactured from low-grade lumber. 


\section{LITERATURE CITED}

Brown, N. C. and J. S. Bethel, Lumber 2d ed. New York: Wiley, 1958.

Christensen, W. W., H. H. Webster, G. Baker, N. A. Norton, and W. H. Reid, Marketing of Lumber by Sawmills in the Northeast-Phase 1. W.Va. Agr. Exp. Sta. Bull. 478. Morgantown, 1962.

Hardwood Market Report, Lumber News Letter. Memphis, Tennessee: Abe Lemsky, 1957.

Holland, I. I. and G. G. Judge, "Estimated Interregional Flows of Hardwood and Softwood Lumber." Journal of Forestry, Vol. 61 (July, 1963), pp. 488-97.

Nellis, J. C. and J. T. Harris, Wood Industries of West Virginia. West Virginia Department of Agriculture, in cooperation with the United States Department of Agriculture, Forest Service, 1914.

"1958 Lumber Production of Major Western Sawmills." The Lumberman, April, 1959 , p. 50.

"1958 Lumber Production of Southern-Eastern Mills." The Lumberman, May, 1959, p. 27.

Reid, W. H., W. W. Christensen, and N. D. Jackson, Interim Report, Marketing Lumber Produced by Sawmills in West Virginia, Phase I and II. W. Va. Agr. Exp. Sta. Morgantown, 1961.

Savage, Job K., "Report of the Select Committee on Small Business, United States Senate, The Problems of the Independent Logging and Sawmill Industry," Appendix I. 86th Congress, First Session, Report 240, p. 104-10.

Steer, H. B. Lumber Production in the United States, 1799-1946. U.S.D.A. Miscellaneous Publication 669. Washington: G.P.O., 1948.

West Virginia Department of Agriculture and U. S. D. A., West Virginia Forest Products Market Information. Charleston, 1960.

West Virginia Department of Natural Resources, Forest Products Price Bulletin. Milton (District Five), Nov., 1962.

West Virginia University, in cooperation with the Conservation Commission, Division of Forestry, 1959 Directory of Sawmill Operators in West Virginia. Morgantown, (mimeo.), 1959.

Whitmore, R. A., P. R. Hagenstein, W. H. Reid, and D. E. Nelson, Marketing of Lumber in the Northeast-Phase 11-Lumber Purchases by Wood Products Manufacturers. Vt. Agr. Exp. Sta. Bull. 635. June, 1963.

Zaremba, Joseph, Economics of the American Lumber Industry. New York: Robert Speller and Sons, 1963. 
Lithographed in West Virginia

by

Biggs-Johnston-Withrow

Beckley 

